Article

\title{
Landslides and Subsidence Assessment in the Crati Valley (Southern Italy) Using InSAR Data
}

\author{
Giuseppe Cianflone $^{1, *(\mathbb{D})}$, Cristiano Tolomei ${ }^{2}$ (D) , Carlo Alberto Brunori ${ }^{2}(\mathbb{D})$, Stephen Monna ${ }^{2}$ \\ and Rocco Dominici ${ }^{1}$ \\ 1 Department of Biology, Ecology and Earth Science, University of Calabria, 87036 Arcavacata di Rende (Cs), \\ Italy; rocco.dominici@unical.it \\ 2 Istituto Nazionale di Geofisica e Vulcanologia (INGV), 00143 Roma, Italy; cristiano.tolomei@ingv.it (C.T.); \\ carloalberto.brunori@ingv.it (C.A.B.); stephen.monna@ingv.it (S.M.) \\ * Correspondence: giuseppe.cianflone@unical.it; Tel.: +39-09-8449-3508
}

Received: 9 October 2017; Accepted: 6 February 2018; Published: 10 February 2018

\begin{abstract}
In this work, we map surficial ground deformations that occurred during the years 2004-2010 in the Crati Valley (Southern Italy). The valley is in one of the most seismically active regions of the Italian peninsula, and presents slope instability and widespread landslide phenomena. We measured ground deformations by applying the small baseline subset (SBAS) technique, a multi-temporal synthetic aperture radar interferometry (InSAR) methodology that is used to process datasets of synthetic aperture radar (SAR) images. Ground displacements are only partially visible with the InSAR technique. Visibility depends on the geometry of the acquisition layout, such as the radar acquisition angle view, and the land use. These two factors determine the backscattering of the reflected signal. Most of the ground deformation detected by InSAR can be attributed to the gravitational mass movements of the hillslopes (i.e., landslides), and the subsidence of the quaternary deposits filling the valley. The movements observed along the valley slopes were compared with the available landslide catalog. We also identified another cause of movement in this area, i.e., ground subsidence due to the compaction of the quaternary deposits filling the valley. This compaction can be ascribed to various sources, such as urban population growth and sprawl, industrial water withdrawal, and tectonic activity.
\end{abstract}

Keywords: SBAS-InSAR; Crati Valley; Southern Italy; subsidence; landslides; salt mine

\section{Introduction}

Ground deformation can be measured by SAR interferometry (InSAR; [1]), a technique applied on data acquired by satellite synthetic aperture radar (SAR) sensors. InSAR involves the processing of two images of a target area acquired by a satellite at different times. More recently, differential InSAR (DInSAR) algorithms, such as permanent scatterers (PS; [2]), the small baseline subset (SBAS; [3]), or a combination of the two [4,5], have been developed. These algorithms, which are based on the interferometric analysis of large image datasets, allow us to follow ground displacement in time.

SAR datasets have been widely employed to analyze different types of ground movements, such as subsidence [6-9], landslides [10-12], deformations associated with active and quiescent faults [12-15], and volcanic activity [16,17]. Discrimination between the different causes of ground displacement that take place in an area of interest is a challenging task.

Our study site, the Crati Valley (CV, Figure 1), which is located in Southern Italy (Calabria Region), is one of the most risk-prone areas of the Italian peninsula, as defined by the official Italian territory seismic classification (Official Gazette No. 105 of 8 May 2003; Figure 2). The CV is a north-south (N-S) oriented graben where landslides along valley slopes and vertical displacement (subsidence) in the 
alluvial plain occur. Ground displacement in this area can be driven by geolithology, geomorphology, and possibly seismic activity.

We try to discriminate the different causes of ground displacement by comparing observations of ground velocity and deformation patterns obtained with the InSAR remote sensing technique, with information from independent sources for the CV. This information comes from geology, geomorphology, stratigraphy, hydrogeology, and seismological studies of recent and historical events in the area. Surface movements are reconstructed from the velocity field of the displacement patterns retrieved from SAR data acquired by the Envisat satellite operated by the European Space Agency (ESA) between 2004 and 2010.

We also investigate the landslide phenomena along the valley sides, by applying a priori InSAR landslide visibility zonation [10]. Mean ground velocity maps are obtained by processing the Envisat data with SBAS, and comparing it to a landslides catalog (PAI-Piano Stralcio di Bacino per l'Assetto Idrogeologico, http:/ / webgisabr.regione.calabria.it/webgis/; latest access 3 March 2016). In this way, we can evaluate the level of activity of the landslides classified in PAI, and look for landslides not included in the catalog. We also take into account the compaction of alluvial deposits caused by groundwater exploitation and loading due to constructions as a contributing factor to the observed vertical displacement. Finally, we try to determine whether the displacement signals we observe might contain a contribution coming from tectonic processes.

\section{Geological Setting}

The CV is a N-S oriented graben bounded by two morphostructural highs: the Sila Massif to the east, and the Coastal Range to the west. The graben is controlled by an array of normal faults along both sides (Figure 1), the so-called Crati fault system [18]. This area, which is part of the Siculo-Calabrian rift zone [19], is the result of the back arc extension due to the opening of the Tyrrhenian Sea [20]. The relationship between the evolution of the Calabrian Arc and Southern Apennines is still debated [21-24]. Tansi, C. et al. interpret the CV as an active transextensional area that developed since the late Pliocene, and as the southeast termination of the Falconara-Carpanzano strike-slip fault [23]. Spina, V. et al. explained the development of the CV, since the middle Pleistocene, as due to the activity of the N-S oriented, east and west-dipping normal faults bounding the valley [24]. These faults probably developed as a response to the uplift of the orogenic edifice, and the extension of the Tyrrhenian back arc.

The faults bounding the $\mathrm{CV}$ show persistent activity with medium-grade seismicity $(5.5<\mathrm{M}<6 ;[18,21,23,25])$. Earthquakes occurred during the time covered by our SAR data, as reported in the INGV (National Institute of Geophysics and Volcanology) catalogue (ISIDe working group 2016; Figure 2). Focal mechanisms of recent earthquakes (Figure 2; [25-27]) agree with the extensional tectonics attributed by several authors to this sector of the northern Calabrian Arc (e.g., $[24,28])$. An extensional trend along the east-west (E-W) axis is also shown by permanent GNSS (Global Navigation Satellite Systems) stations [29].

The stratigraphy of the $\mathrm{CV}$, starting from the Upper Miocene to the Holocene, is characterized by deposits covering a nonconformity that overlies the Palaeozoic crystalline bedrock. The deposits have increasing thickness from the Coastal Range towards the Sila Massif [24,30] (Figure 1). The Upper Miocene succession, which also includes Messinian evaporites [31], outcrops discontinuously along the western side of the CV. The Pliocene and Plio-Pleistocene successions, which are visible along the western side of the valley, are separated by angular unconformities and constituted by deltaic (Gilbert-type and shelf-type deltas) and coastal deposits [32,33]. The Plio-Pleistocene sediments outcrop along both sides of the valley where they lie, along a nonconformity, directly on Paleozoic bedrock [18]. 

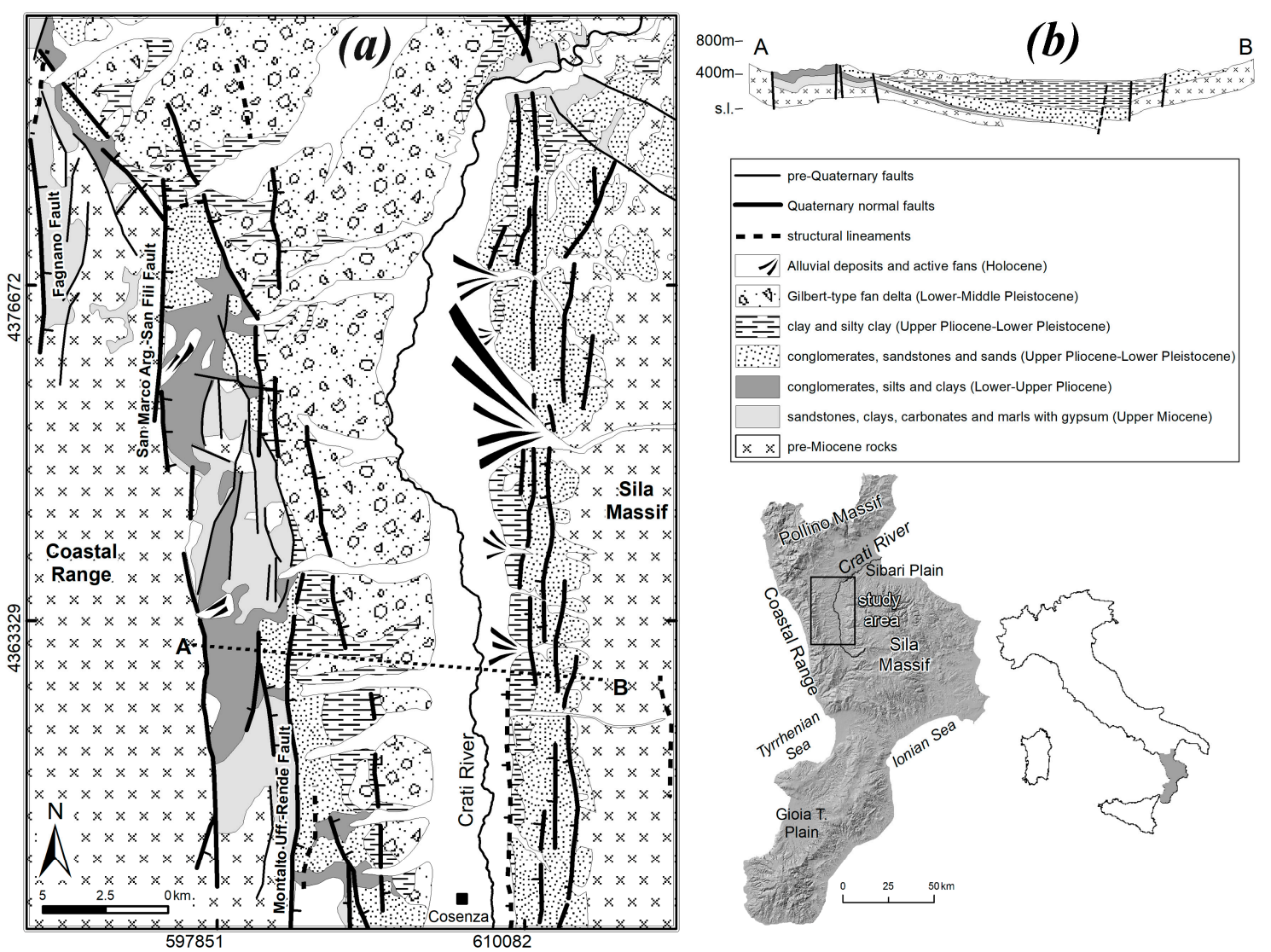

Figure 1. (a) Geological map and (b) cross-section of the Crati Valley (redrawn from [24]).

High relief energy, steep slopes, and severe tectonic fracturing drive shallow and deep-seated gravitational deformations along both the east and west sides of the CV [34-36].

The alluvial plane of the CV presents the subsidence of recent deposits, which is similar to the other Quaternary basins of Calabria (Sibari and Gioia Tauro plains) that are adjacent to the CV (Figure 1). In particular, the Gioia Tauro Plain is similar to the CV in its geological evolution. Both basins belong to the so-called Siculo-Calabrian rift zone (SCRZ) [19], are characterized by crustal extension, and are bounded by normal faults that have produced strong earthquakes in historical times. In the Gioia Tauro Plain, subsidence rates of 10-15 mm/year between 1992-2006 are considered to be caused exclusively by groundwater withdrawal [37]. In the Sibari Plain, where the CV estuary is located, subsidence rates up to $20 \mathrm{~mm}$ /year are ascribed to a coaction of natural and anthropogenic factors [38]. 


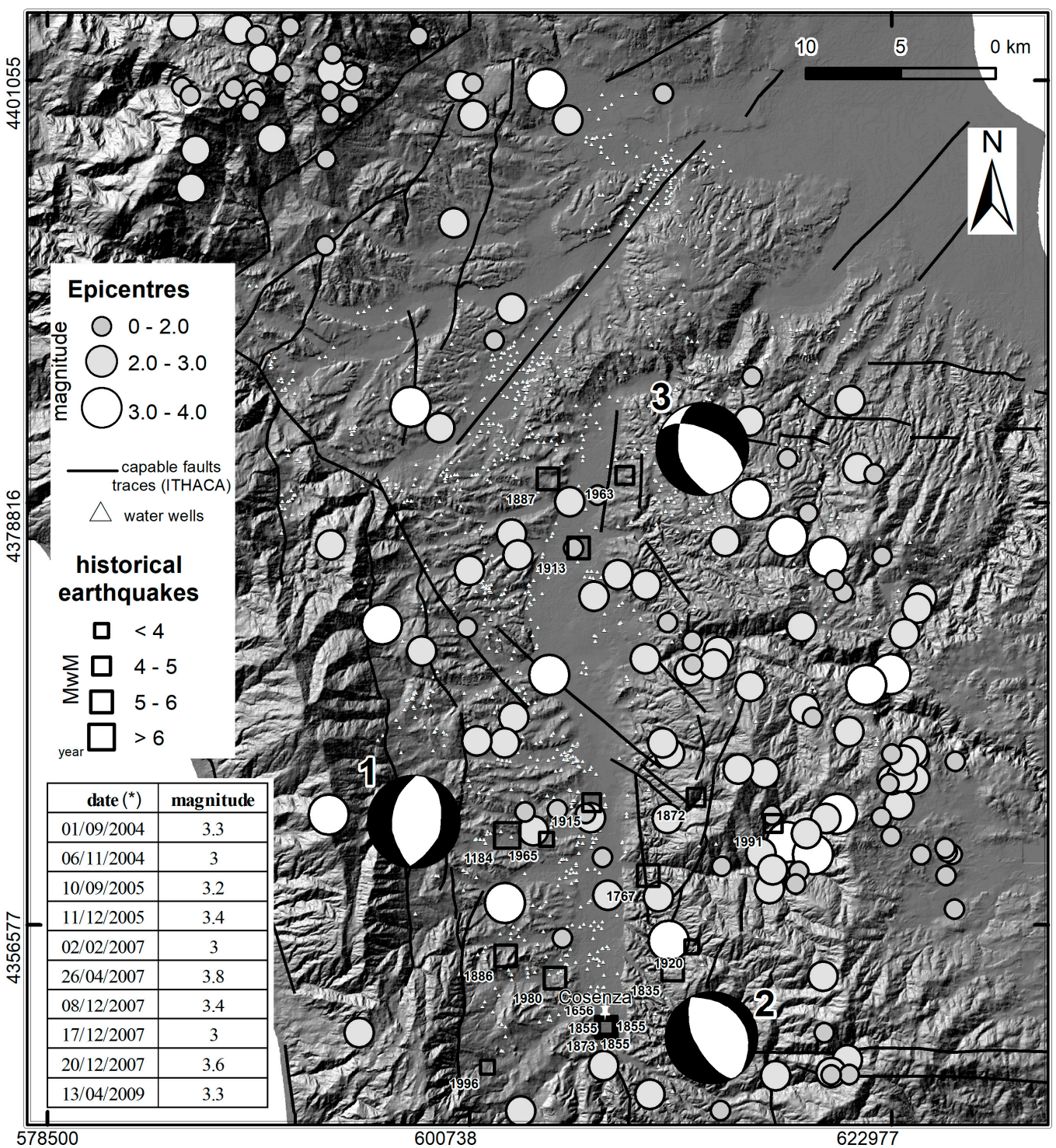

Figure 2. 2003-2010 earthquakes epicenters in the study area (Italian Seismological Instrumental and parametric Data-base (ISIDe) database). Black lines represent "capable faults" (Ithaca database [39]). Focal mechanisms show a major extensional horizontal stress: (1) [25], 20 February 1980, ML = 4.3; (2) [25], 18 October 2001, MW = 4.4; (3) [26], 26 April 2007, MW = 3.8. In the table the date and magnitude of the $M>3$ earthquakes are listed, which occurred in the area during the period of Envisat dataset acquisition. The map also shows historical earthquakes from CPTI15 [40].

\section{Remote Sensing Processing Technique}

SAR interferometry (InSAR) is a technique that, starting from airborne or spaceborne synthetic aperture radar (SAR) image data, measures the ground surface movements that take place within two acquisitions (e.g., passages of the satellite) over the same area. It is based on the radar concept, that is, the phase of the radar signal returned at the satellite conveys quantitative information on the change in the sensor-to-ground distance caused by the deformation of the detected surface [1,41,42]. By subtracting the phase of the two images, a differential interferogram containing displacement signals is formed after the removal of the phase contributions due to: the topographic relief (using a digital elevation model, or DEM); the earth curvature; the atmospheric contribution due to the atmospheric humidity, temperature, and pressure change between the two acquisitions; the noise introduced by temporal change of the scatterers; a different look angle; and volume scattering [1,41]. 
With InSAR, a non-intrusive and non-destructive technology, the accuracy in the measurement of the surface movements depends on various factors (atmospheric effects, orbital effects, stability of ground scatterers, unwrapping errors, the wavelength of the signal, etc.). In favorable cases, relative displacement can be detected over time within sub-centimeter accuracy [43]. An order of magnitude improvement in accuracy has been achieved with the development of time series differential SAR interferometry (DInSAR) down to $\sim 1 \mathrm{~mm} /$ year [44].

In this work, we adopted the SBAS multi-temporal InSAR technique [3] to obtain the displacement time series and the mean ground velocity map. The SBAS algorithm is based on a combination of many SAR differential interferograms that are generated by applying constraints on the temporal and perpendicular baselines. The inversion of the interferometric phase, performed with the singular value decomposition (SVD) technique, produces a ground displacement time series for each coherent pixel, by minimizing possible topographic, atmospheric, and orbital artifacts $[2,3,44,45]$.

We used the SBAS algorithm on the Geohazard Exploitation Platform (GEP), which was developed by ESA (https://geohazards-tep.eo.esa.int). This SBAS version performs three-dimensional (3D) unwrapping through the algorithm proposed by Pepe, A. and Lanari, R. [46]. Atmospheric contribution is removed by "standard" filtering in time and space. In the current online version, no external atmospheric model is implemented. Detailed information about the SBAS version working on the GEP is available at https: / / geohazards-tep.eo.esa.int, and in De Luca, C. et al. [47].

The processing of Envisat data produces velocity maps in the line of sight (LoS) of satellite SAR geometry (data acquisitions in both ascending and descending orbits). Vertical (up-down) and horizontal $(\mathrm{E}-\mathrm{W})$ ground velocity components can be derived by combining ascending and descending LoS velocities. We considered two Envisat datasets (Table 1) containing 32 images acquired for the descending track in the time interval 2004-2010, and 38 images for the ascending track acquired in 2003-2010. For each dataset, we selected pairs of images by applying constraints on the maximum orbital separation, and the temporal distance between the two passages. The effect of this constraint is to minimize spatial and temporal decorrelation effects [3]. In particular, we chose $350 \mathrm{~m}$ and 700 days as the maximum values for the perpendicular and temporal baselines, respectively. We used the 90-m SRTM (Shuttle Radar Topographic Mission) digital elevation model (DEM) for the topography subtraction step ([48]; http://www2.jpl.nasa.gov/srtm). Processing was performed, for both the ascending and descending data, by applying a multi-looking factor equal to 20 for the azimuth, and 4 for the range direction, resulting in a final ground resolution of $90 \mathrm{~m}$.

Table 1. Used image datasets. Ground resolution values are obtained after a multi-looking operation.

\begin{tabular}{cccccccc}
\hline Satellite & Orbit Type & Track/Beam & $\begin{array}{c}\text { N. of Used } \\
\text { Images }\end{array}$ & $\begin{array}{c}\text { Number } \\
\text { of Pairs }\end{array}$ & $\begin{array}{c}\text { Temporal } \\
\text { Span }\end{array}$ & $\begin{array}{c}\text { Ground } \\
\text { Resolution (m) }\end{array}$ & $\begin{array}{c}\text { Incidence } \\
\text { Angle }\left({ }^{\circ}\right)\end{array}$ \\
\hline Envisat & Ascending & 86 & 26 & 137 & $\begin{array}{l}04 / 05 / 2003 ; \\
19 / 09 / 2010\end{array}$ & 90 & 23 \\
Envisat & \multirow{2}{*}{ Descending } & 222 & 17 & 115 & $\begin{array}{c}27 / 08 / 2003 ; \\
25 / 08 / 2010\end{array}$ & 90 & 23 \\
\hline
\end{tabular}

DInSAR observations derived from ascending and descending orbits allow us to decompose the E-W and the vertical components of the detected deformation. The sum and the difference applied to the mean deformation velocities, which was computed for the ascending and the descending orbits, are calculated for all of the pixels that are coherent in both geometries. Given the namely near-polar sensor orbit direction, the north-south (N-S) component of the deformation cannot be reliably derived.

To retrieve the E-W and vertical components of deformation, the following assumptions are made: (i) ascending and descending radar LoS directions (LoS Asc and LoS Desc, respectively) can be considered as lying on the plane containing the east and $\mathrm{z}$ directions; and (ii) the sensor incidence angle $\vartheta$ is the same for both ascending and descending geometries. Then, assuming the availability of the displacement measurements along both the ascending $\left(\mathrm{d}_{\text {LoS_Asc }}\right)$ and the descending $\left(\mathrm{d}_{\text {LoS_Desc }}\right)$ radar LoS directions, on the basis of simple geometric considerations, we can calculate $\mathrm{d}_{\text {East }}$, which is 
the $\mathrm{E}-\mathrm{W}$ component of the measured surface deformation for a target that is "observed" from both the ascending and the descending satellite passages:

$$
\mathrm{d}_{\text {East }}=\left(\mathrm{d}_{\text {LOS_Desc }}-\mathrm{d}_{\text {LoS_Asc }}\right) / 2 \sin \theta
$$

while the vertical component, $\mathrm{d}_{U \mathrm{Up}}$, is:

$$
\mathrm{d}_{\mathrm{Up}}=\left(\mathrm{d}_{\text {LOS_Desc }}+\mathrm{d}_{\text {LoS_Asc }}\right) / 2 \cos \theta
$$

where $\theta$ is the incidence angle at center swath ( $23^{\circ}$ for ASAR-Envisat data), and $d_{\text {LoS_Desc }}$ and $d_{\text {LoS_Asc }}$ are the descending and ascending velocities for all of the overlapping pixels, respectively.

We validated InSAR LoS velocities through comparison with measurements at CGPS (Continuous Global Positioning System) sites [44] projected on the same ground elements. GPS velocity and its error were projected on the ascending and descending SAR LoS. To compare the two measurements, we averaged the InSAR velocities in a circular buffer (200-m radius) centered on each GPS benchmark. The velocity differences did not exceed $\pm 1.5 \mathrm{~mm}$ /year for both the ascending (Figure 3c) and descending (Figure 3d) tracks.
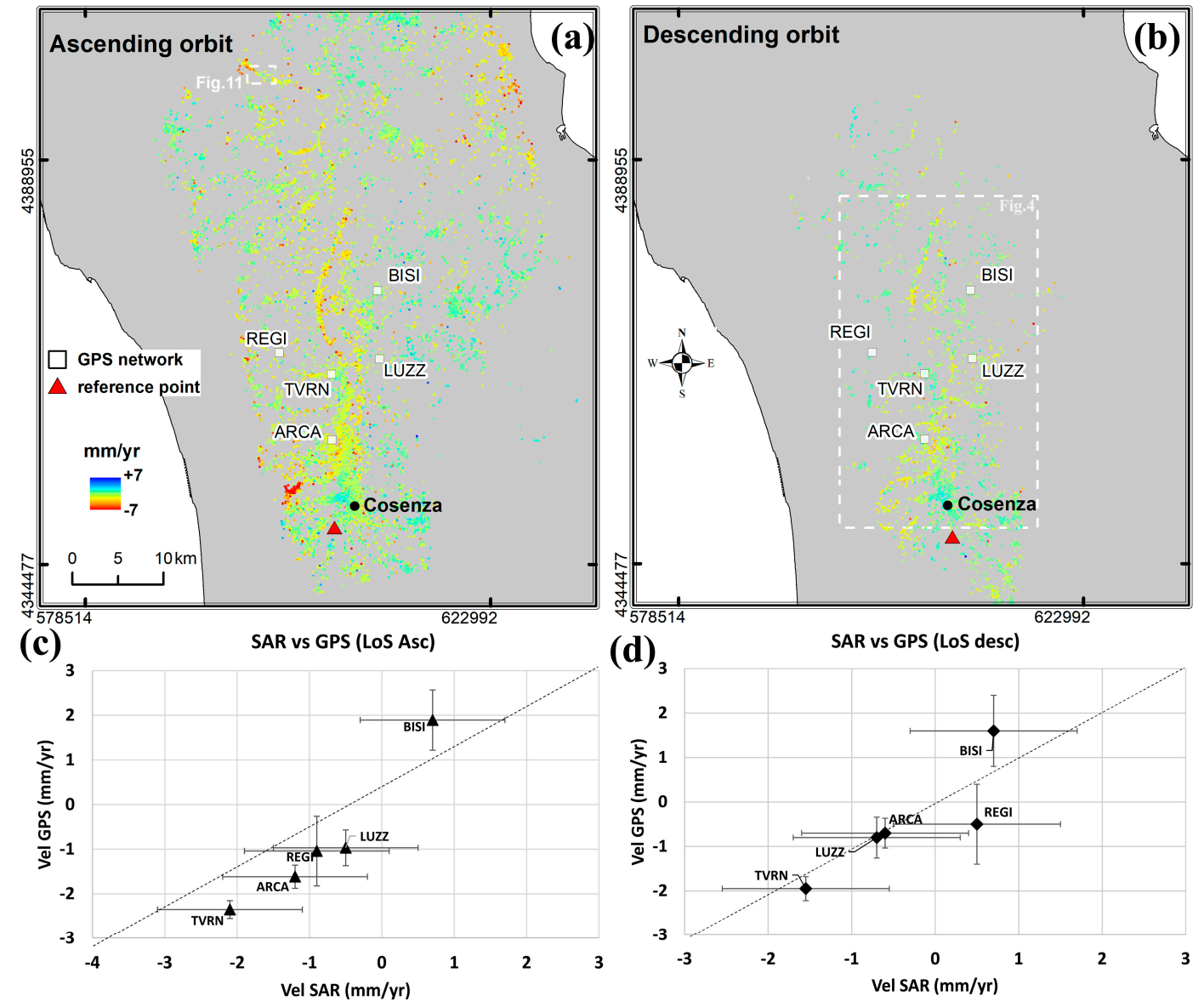

Figure 3. Envisat ascending (a) and descending (b) line of sight (LoS) ground velocity maps. The red triangle represents the stable point (stable means that the mean velocity is $0 \mathrm{~mm}$ /year), which is used as a reference point. White squares are the GPS benchmarks, which are used for the validation of the retrieved results. Comparison between the LOS synthetic aperture radar (SAR) ascending (c) and descending (d) velocities and GPS shows a correlation coefficient of 0.96 and 0.86 , respectively. 
Ground visibility depends on the angle formed by the satellite's LoS and the surface slope. Areas located along the eastern CV sides are more visible on Envisat ascending tracks, while areas on the western side are more visible on the descending tracks. The quality of our data for the CV area, then, depends on acquisition geometry and visibility, which in turn depend on the alluvial plain's disposition in space. (Figure 4).

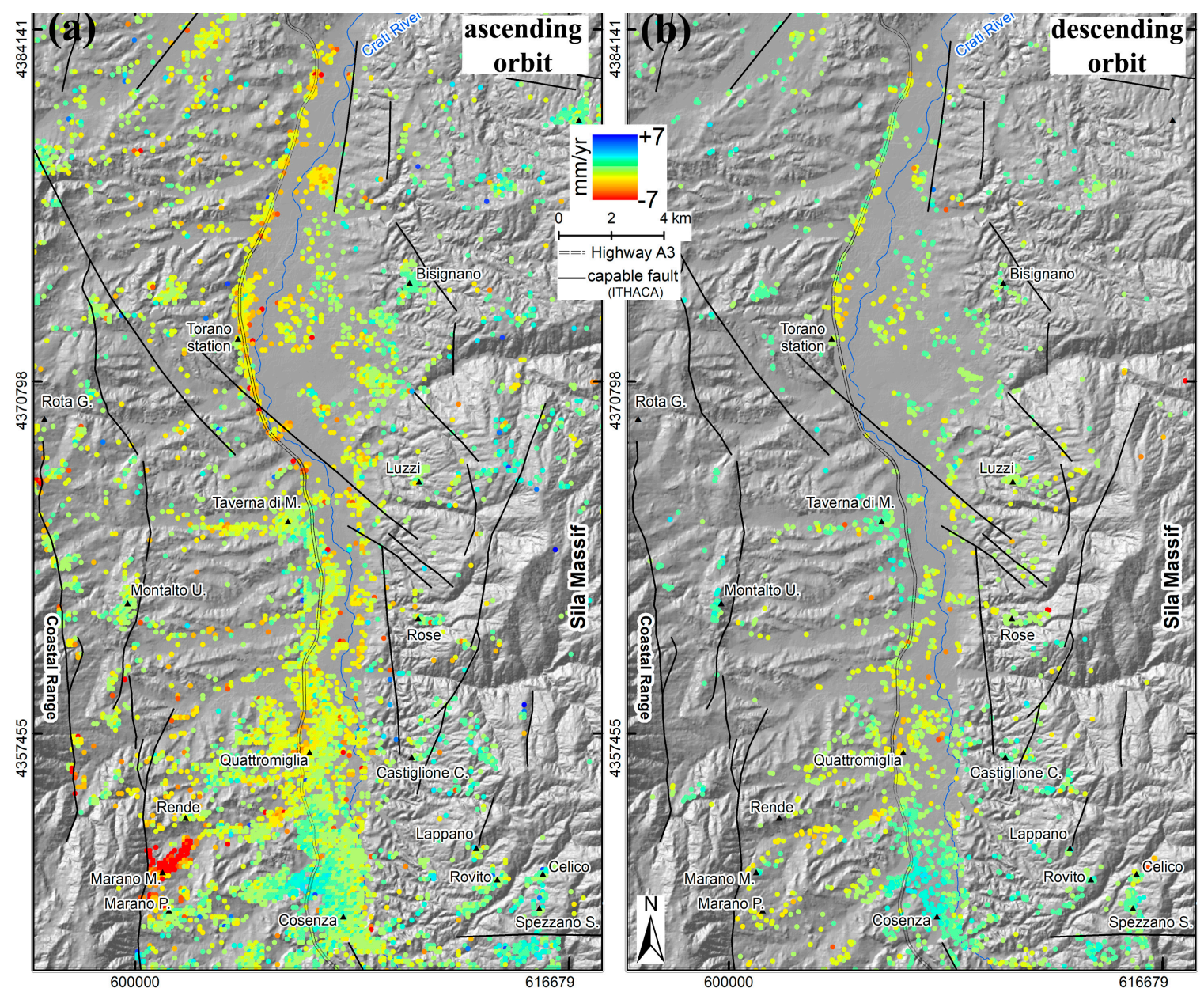

Figure 4. Zoom of the (a) ascending and (b) descending LoS ground velocity maps for the Crati Valley area. The spatial distribution of pixels appears as a regular grid after rounding the coordinates to significant digits. The "capable faults" of the Ithaca database [38] are plotted on the maps.

\section{Results}

\subsection{Alluvial Plain}

The vertical component (Figure 5a) shows several subsiding areas, of approximately $-7 \mathrm{~mm} /$ year, in the flat part of the valley near populated areas such as the suburbs of Rende town (Quattromiglia; inset in Figure 5b). The Quattromiglia urban area underwent a fast growth during the last 50 years, as confirmed by images acquired at different times (Figure 6a). The ascending time series shows an increase of movement away from the sensor (mainly related to subsidence) in two of the five sites within zones 1 and 2 in the Quattromiglia area (Figure 6b), where urban sprawl has occurred. Only a small displacement is present in zone 3 (industrial area), and stability ( $\sim \mathrm{mm} /$ year) is detected in zones 4 and 5, which have not been affected by urban expansion (Figure 6b). The descending time series (Figure $6 b$ ) confirms that the largest displacement is in zones 1 and 2 , and that displacement is small or absent in the other zones $(3,4$, and 5$)$. 


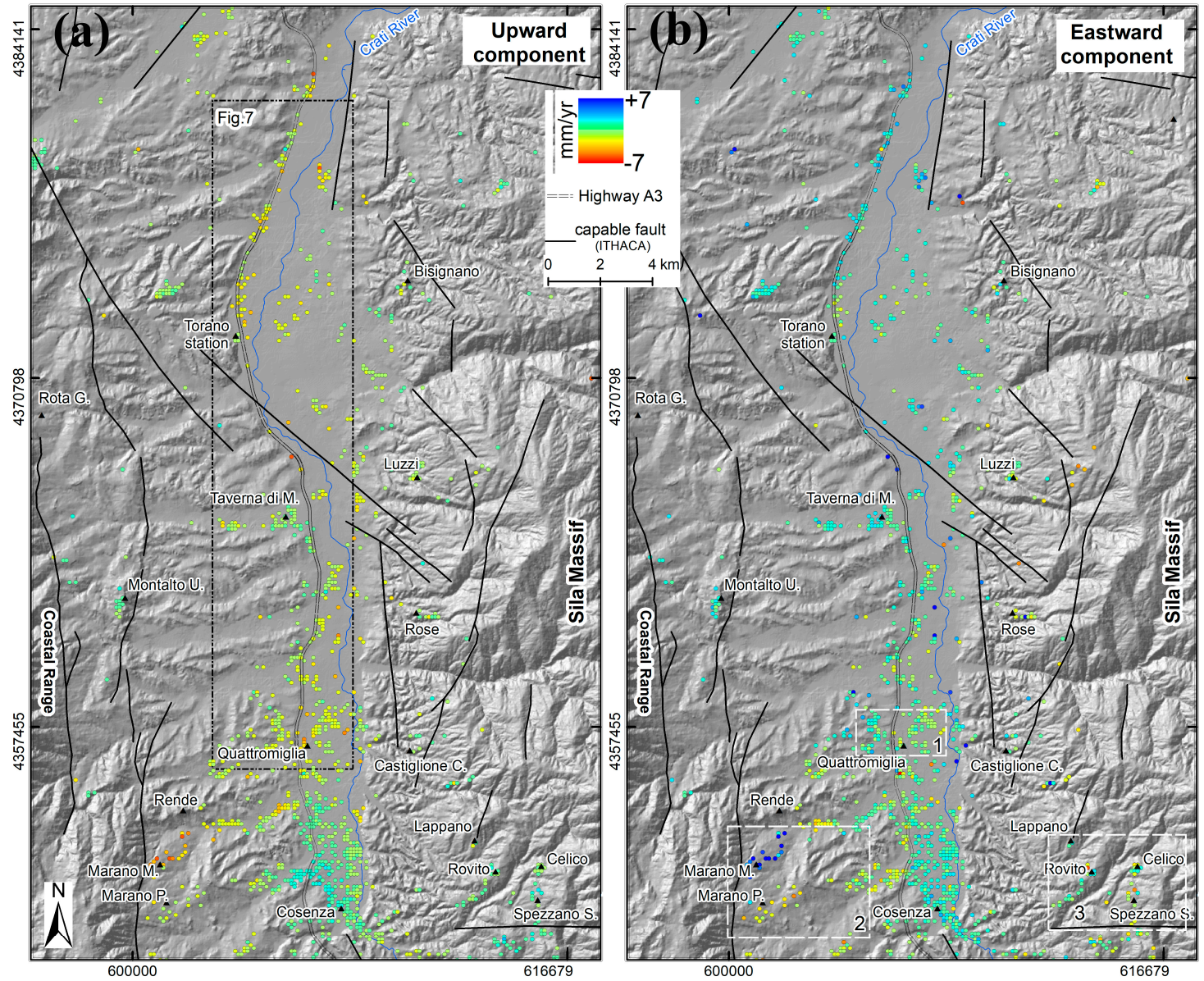

Figure 5. Vertical (upward) and east-west (east) components computed from Envisat dataset for the Crati Valley. (a) Upward ground velocity component; positive values indicate uplift and negative values indicate subsidence; (b) east ground velocity component; positive values indicate eastward movement, and negative values indicate westward displacements. As explained in the main text, the flat part along the north-south $(\mathrm{N}-\mathrm{S})$ direction is the central sector, while its flanks are the eastern and western sectors. The "capable faults" of the Ithaca database [38] are plotted on the maps.

To check for hydrogeological effects in the same area, we compared the water table level of 1979 (Celico, F. et al. [49]) with the piezometric levels of two more recent periods, 1990-1992 and 2000-2005, using the "Indagini Nel Sottosuolo" dataset (http:/ / sgi.isprambiente.it/GMV2/index.html). Our goal is the reconstruction of the long term variations of the water table without taking into account seasonal oscillations, since they cannot be investigated with the available piezometric data. From these data, we derived a map of water table variations during the periods 1979-1992, 1990-2005, and 1979-2005 (Figure 7a-c). During the first period, the main piezometric level decreased in proximity of the Quattromiglia, Taverna di Montalto, and Torano station areas (Figure 7a), where the vertical component showed values between -1 and $-5 \mathrm{~mm}$ /year. In the other two periods, there was a decrease of the water table in the area close to the Crati riverbed, between the Quattromiglia and Torano stations (Figure 7b), where subsidence reached rates up to $5 \mathrm{~mm} /$ year. The water table variation between 1979 and 2005 (Figure 7c) was characterized by a decrease close to Taverna di Montalto and near the Torano station. 

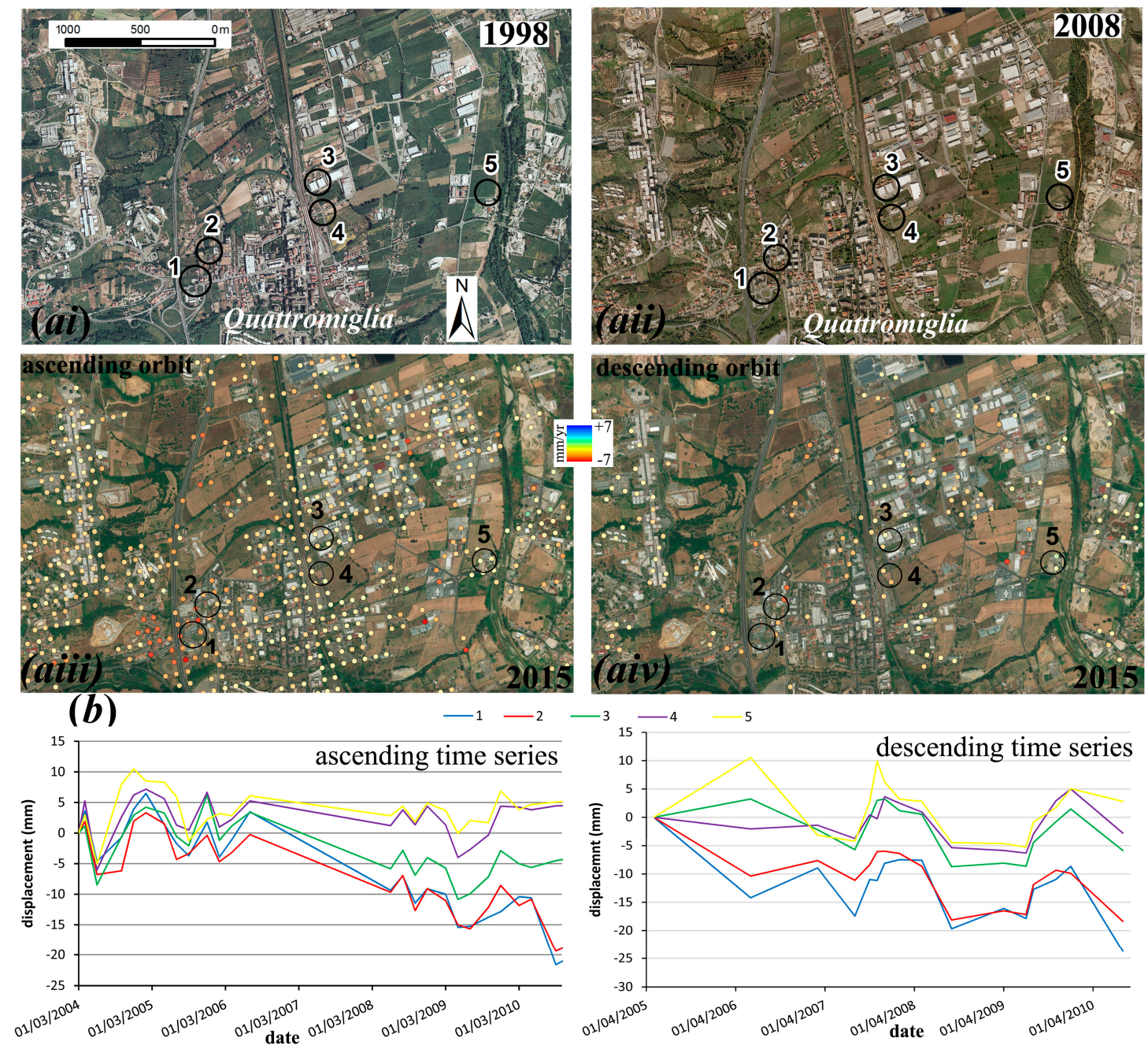

Figure 6. (a) 1998 (ai) and 2008 (aii) maps, from aerial photos of the project IT2000CGR and of Carta Tecnica Regione Calabria (http://pr5sit.regione.calabria.it/web/pr5sit/sezione-opendata1), respectively, showing Quattromiglia urban expansion; Envisat ascending (aiii) and descending (aiv) LoS ground velocity maps projected on the Bing 2015 satellite image of the year (www.bing.com/ mapspreview); (b) ascending and descending time series scatterplot for five sectors (location in (a)) located both inside and outside the main urban expansion area.
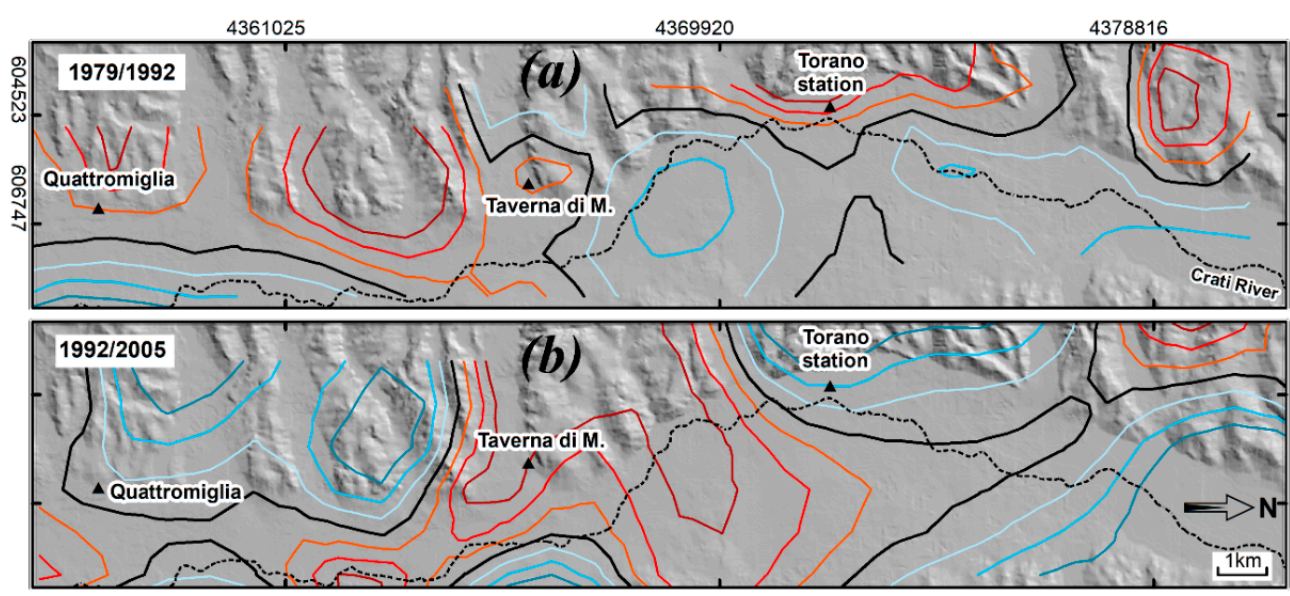

Figure 7. Cont. 

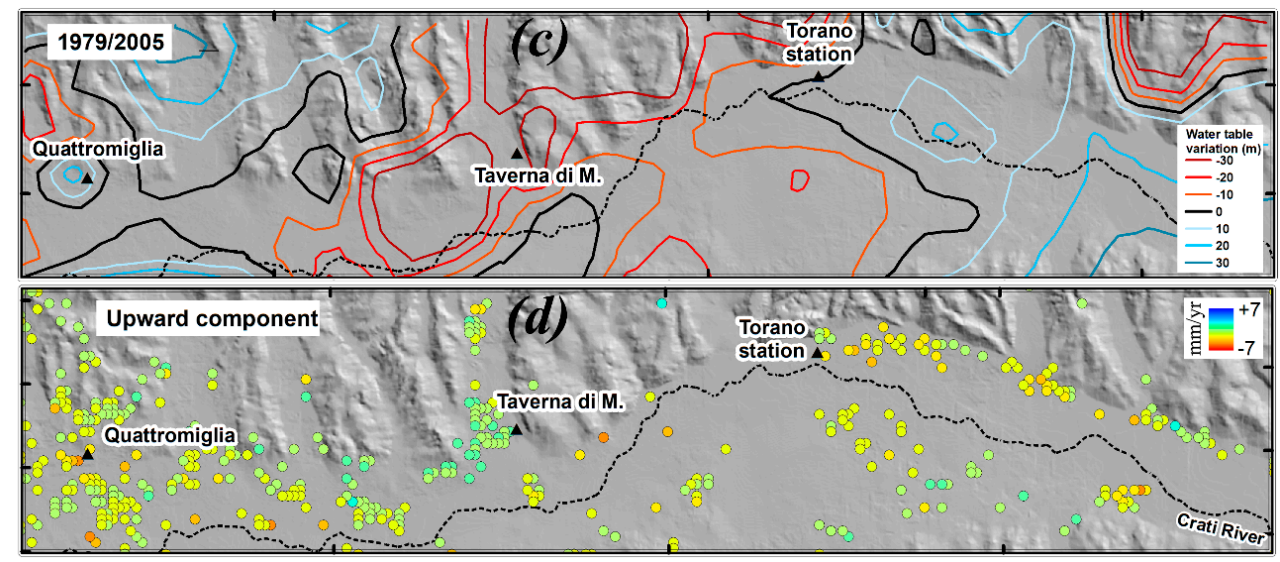

Figure 7. Isolines represent the water table variations (m) in the periods (a) 1979-1992; (b) 1992-2005; and (c) 1979-2005. See the inset in Figure 4 for the location; (d) upward ground velocity component in the Crati Valley $(\mathrm{CV})$ plain.

No significant surface deformation was observed in the correspondence of Cosenza old town with COSMO-SkyMed and ground-based radar sensors data by [50]. In particular, we observed vertical component values of $0.23,0.02$, and $-0.37 \mathrm{~mm} /$ year (Figure 8a) close to the Saint Augustine Monumental compound. This area was investigated in detail by Montuori, A. et al. [50]. In the western sector of Cosenza, the vertical component showed a weak uplift (max value $2.3 \mathrm{~mm}$ /year; mean value $0.76 \mathrm{~mm} /$ year) for parts of the town that were built on Pliocene deposits (clay, sandstone, and conglomerate) and the Quaternary conglomerates representing fluvial terraces (Figure $8 \mathrm{~b}$ ). On the other hand, for the eastern sector, a weak subsidence (up to $1.6 \mathrm{~mm}$ /year) was instead observed for the areas that were built on Quaternary alluvial deposits.

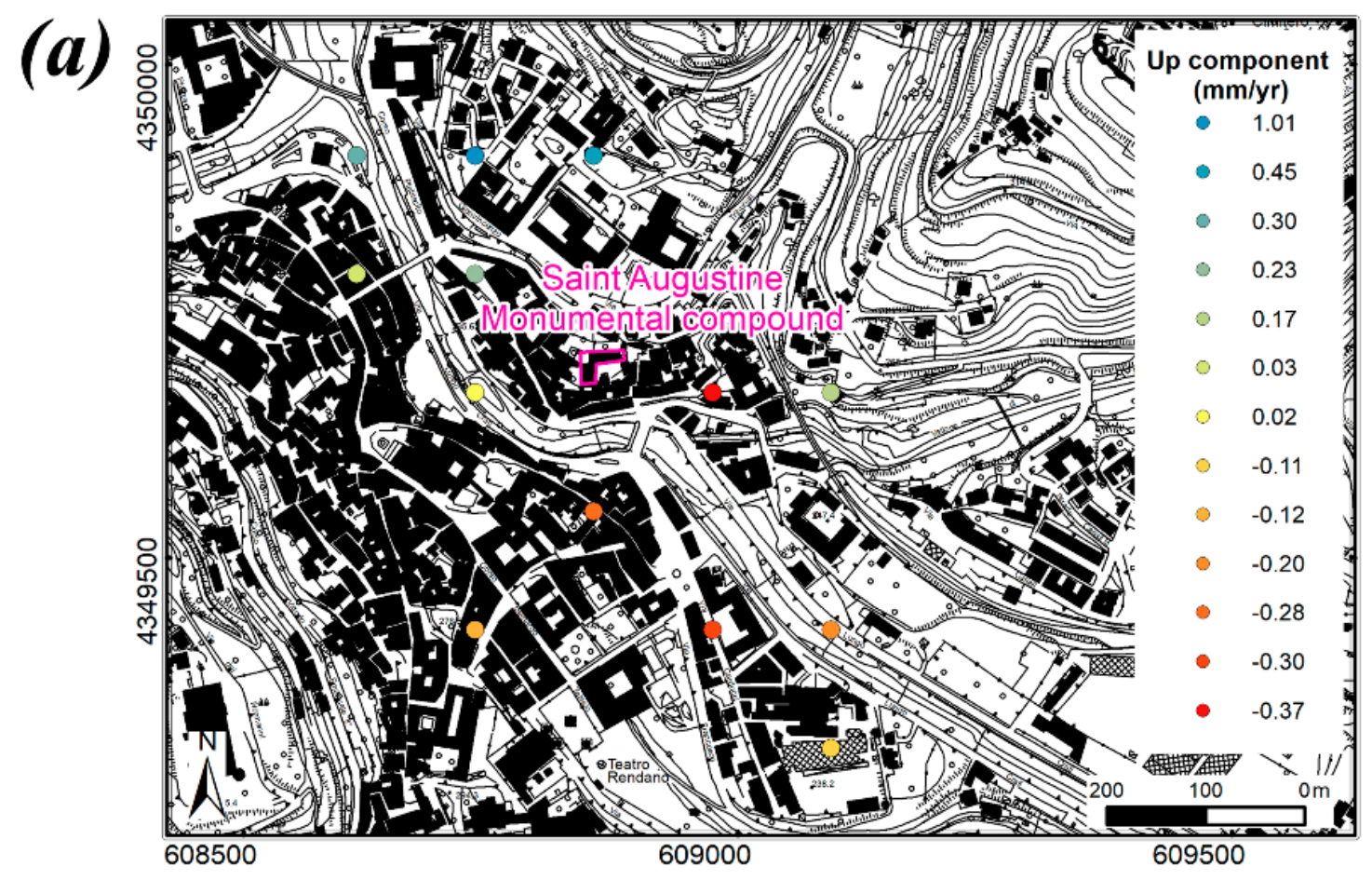

Figure 8. Cont. 


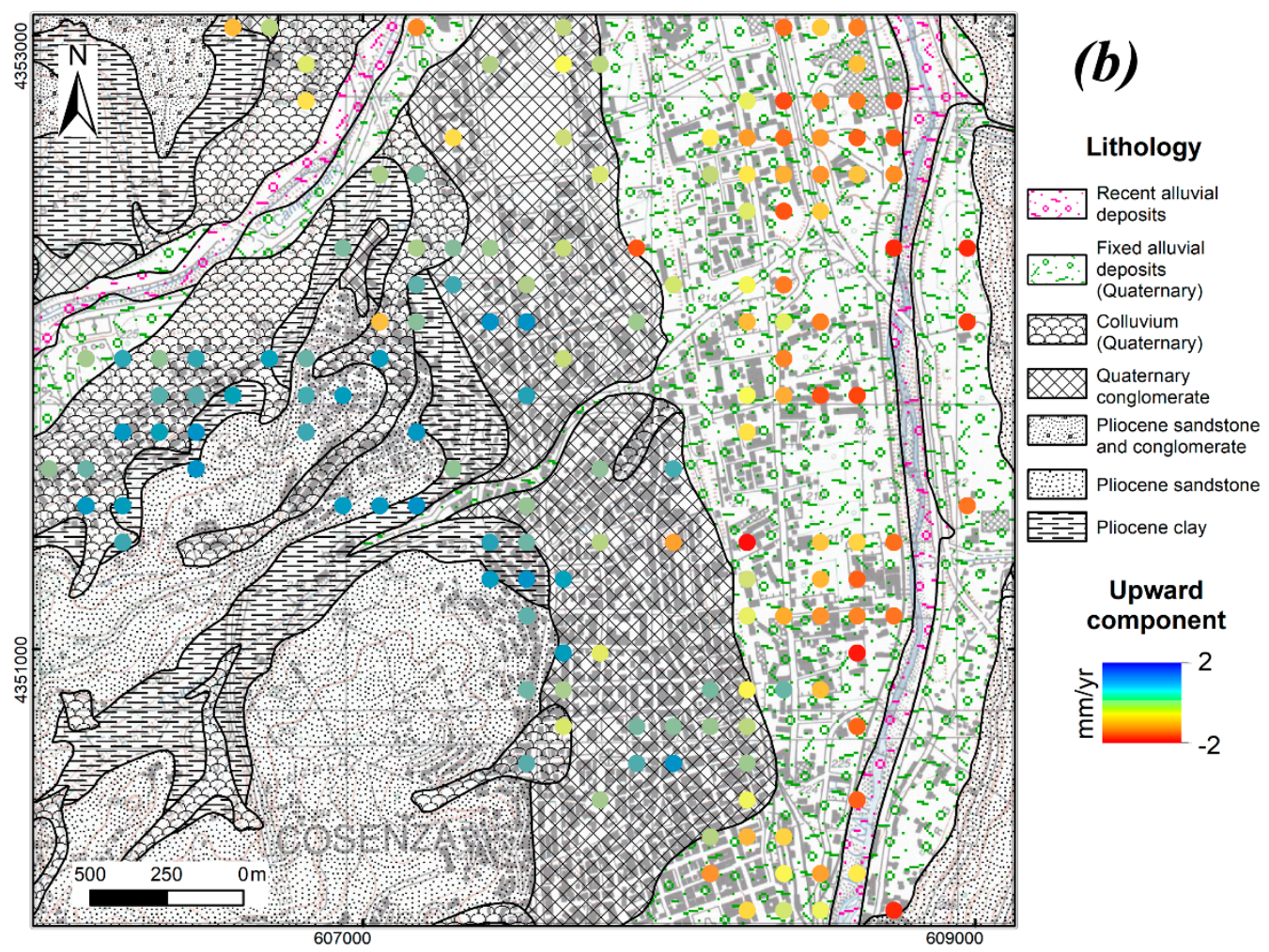

Figure 8. (a) Upward component close to Cosenza old town; (b) upward component in correspondence of other Cosenza areas plotted on a lithological map.

\subsection{Eastern and Western Sides (CV Slopes)}

Subsidence is also locally present along the eastern and western boundaries of the valley (Figure 5a).

Along the valley edges, the horizontal $(E-W)$ displacement component (Figure $5 b$ ) shows both westward movement (negative values) of up to $-15 \mathrm{~mm} /$ year (e.g., Luzzi and Montalto Uffugo villages), and eastward movement (positive values) of up to $\sim 12 \mathrm{~mm} /$ year (e.g., in the area between Castiglione Cosentino and the Rose villages, and close to the Marano Marchesato settlement). Moreover, ground velocity maps identify a large area in the central part of the $\mathrm{CV}$ showing both subsidence and eastward displacement (Figure 5).

CV slopes are affected by widespread gravitative (landslides) phenomena. The PAI map (Figure 9; Table 2), which is based on geomorphological criteria, defines three states of activity ("active", "dormant", and "inactive"), and identifies several typologies of landslide phenomena. In particular, for $\mathrm{CV}$, the landslide inventory distinguishes 586 rotational slides, nine earth flows, six rock falls, two deep-seated gravitational movements, 139 complex landslides, 115 surface landslide areas, and 223 deep landslide areas. Over a total number of 1080 landslides, the CV slopes are characterized by a prevalence of dormant phenomena $(81.3 \%)$ with respect to active $(18.2 \%)$ and inactive $(0.5 \%)$. 

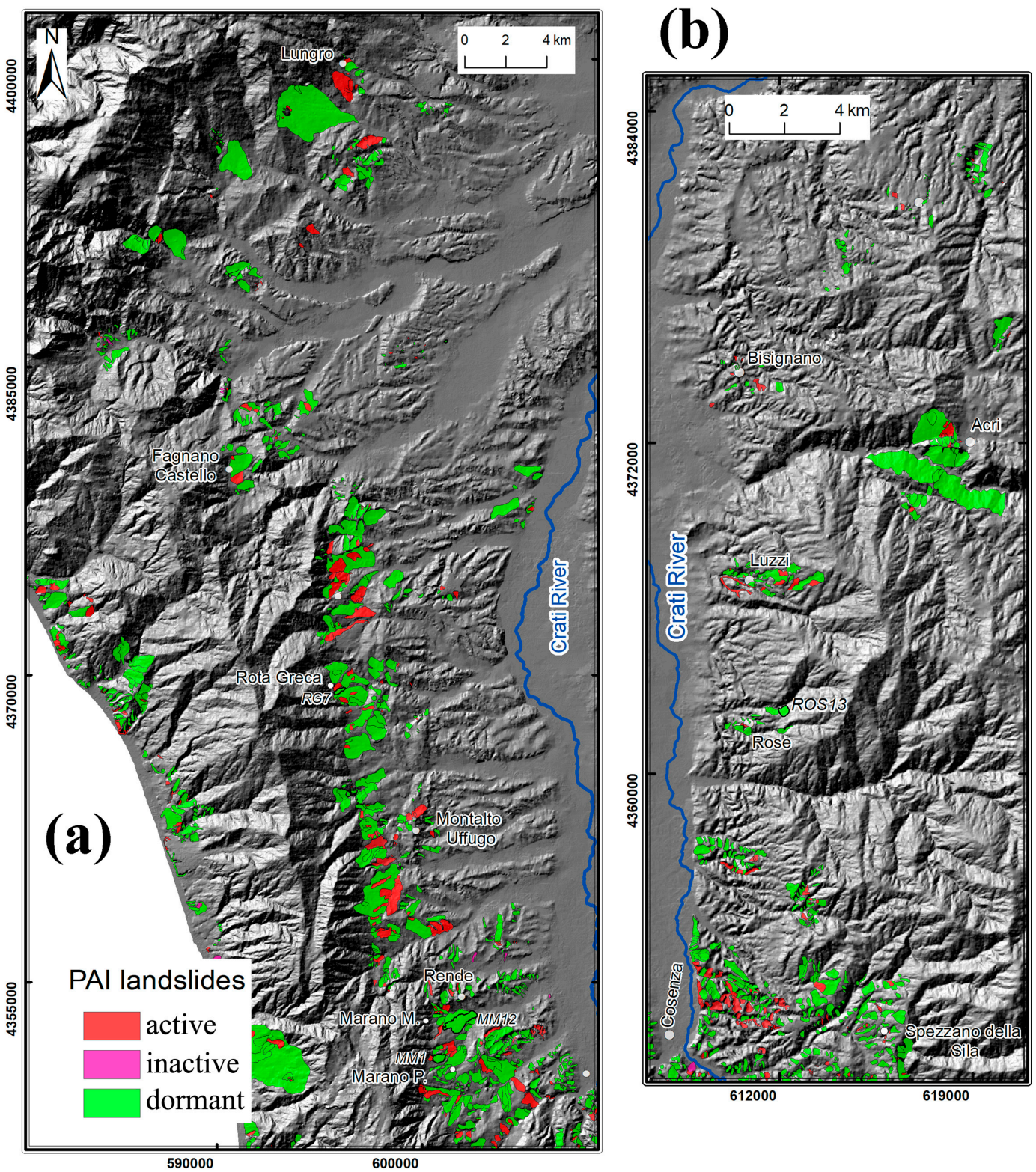

Figure 9. Piano Stralcio di Bacino per l'Assetto Idrogeologico (PAI) landslides map of the (a) western and (b) eastern CV slopes.

Table 2. Number, tipology, and state of activity of landslides mapped in the PAI inventory map.

\begin{tabular}{cccc}
\hline & & State of Activity & \\
\hline Tipology & Active & Dormant & Inactive \\
\hline rotational slides & 83 & 500 & 3 \\
earth flows & 2 & 7 & \\
rock falls & 5 & 1 & \\
deep landslide areas & 49 & 174 & 2 \\
complex landslide & 35 & 102 & \\
surface landslide areas & 23 & 92 & \\
deep-seated gravitational movements & & 2 & \\
\hline
\end{tabular}

Following the method proposed by Cascini, L. et al. [10], we combined the landslide map produced by the PAI project (scale 1:25.000, updated in 2011) with the visibility zoning based on SAR acquisition geometry (Table 3). In this way, we could investigate the potentiality of Envisat data for landslide 
studies at CV using the a priori DInSAR landslide visibility zoning. The PAI catalogue identifies in the area, which extends about $1624 \mathrm{~km}^{2}, 1080$ landslides (about $86.5 \mathrm{~km}^{2}$ ). We divided the SAR data for this area according to the different types of land use (CLC; Corine land cover, 2006-http:/ /wms.pcn. minambiente.it/ogc?map=/ms_ogc/WMS_v1.3/Vettoriali/Corine_Land_Cover2006.map).

Table 3. Geometric features (inclination and slope aspect) used to define the landslide visibility (after Cascini, L. et al. [10] and references therein).

\begin{tabular}{|c|c|c|c|}
\hline & Visible & Visible with Difficulty & Not Visible \\
\hline Descending orbit & $\begin{array}{l}\text { areas facing west, northwest, and } \\
\text { southwest, and exhibiting slope } \\
\text { angles lower than } 67^{\circ}\end{array}$ & $\begin{array}{l}\text { areas facing north } \\
\text { and south }\end{array}$ & $\begin{array}{l}\text { areas facing east, } \\
\text { northeast, and southeast }\end{array}$ \\
\hline Ascending orbit & $\begin{array}{c}\text { areas facing east, northeast, and } \\
\text { southeast, and exhibiting slope } \\
\text { angles lower than } 67^{\circ}\end{array}$ & $\begin{array}{l}\text { areas facing north } \\
\text { and south }\end{array}$ & $\begin{array}{l}\text { areas facing west, } \\
\text { northwest, and } \\
\text { southwest }\end{array}$ \\
\hline
\end{tabular}

The CLC categories are reduced to three classes: "urbanized areas and bare rocks" (class I); "cultivated areas and bare soils" (class II); and "vegetated areas and inland waters" (class III). Class II covers $63.5 \%$ of the total, while classes III and I occupy $33.3 \%$ and $3.2 \%$, respectively. For each class, we computed the number and density of coherent pixels derived from InSAR (Figure 10). For both satellite tracks, the highest coherent pixel density is recorded in class I (102.46 pixels $/ \mathrm{km}^{2}$ and 20.66 pixels $/ \mathrm{km}^{2}$, respectively). Classes II and III correspond to a density of 6.11 pixels $/ \mathrm{km}^{2}$ and 1.25 pixels $/ \mathrm{km}^{2}$ for the ascending orbit, and 1.22 pixels $/ \mathrm{km}^{2}$ and 0.19 pixels $/ \mathrm{km}^{2}$ for the descending orbit, respectively. This analysis confirms that the urbanized areas (class I) are the best in terms of InSAR pixel coherence, while the vegetated areas (class III) are the worst.

(a)

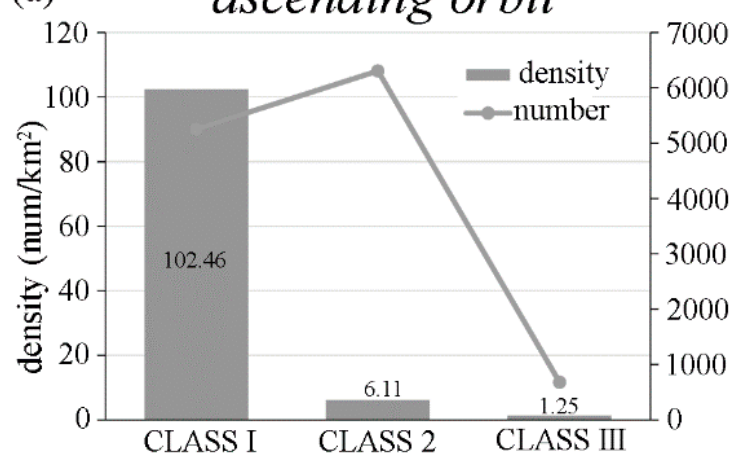

(b) descending orbit

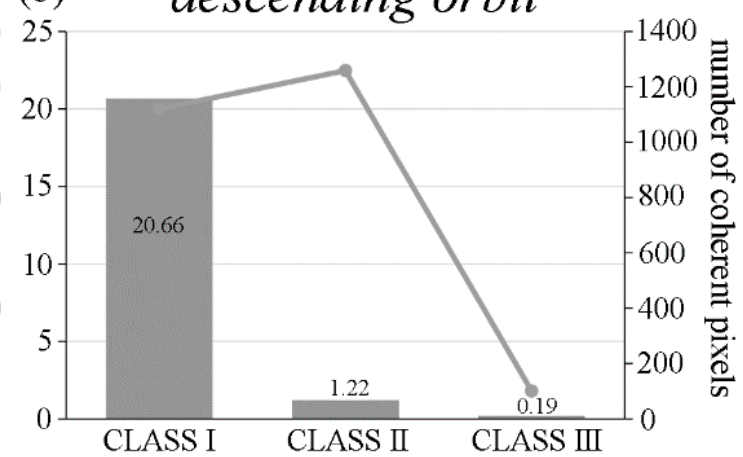

Figure 10. Number and density for the Envisat ascending (a) and descending (b) coherent pixels for the three different land use classes.

We also focused our attention on Lungro village, which is located in the northwest (Figure 11a), where both subsidence and landslides occur [51-54]. Landslides affecting the urban areas have been known to occur in this area since historical times [51,52]. By integrating geological/geomorphological studies, inclinometer measurements, and InSAR data, Antronico, L. et al. [53] explain the damage of buildings as due to slow landslides in the historical center and landslide remobilization in the new urban area (San Leonardo). Guerricchio, A. et al. [54] recorded subsidence of several tens of centimeters affecting San Leonardo hill (Figure 11b).

The Lungro salt mine at the San Leonardo foothill (Figure 11a) has been exploited from the Magna Grecia epoch (starting in the 8th century BC) up until 1976 [55]. The Messinian halite deposits extracted by means of dry mining operations along five levels at different depths that vary from $-90 \mathrm{~m}$ to $-240 \mathrm{~m}$, have a total length of $\sim 400 \mathrm{~m}$, and a width of $\sim 250 \mathrm{~m}$. For this site, only ascending data are available. Three different time series (Figure 11c) were acquired simultaneously in the San Leonardo hill and along the topographic survey profile of Guerricchio, A. et al. [54] (Figure 11b). Ground 
displacements up to $-20 \mathrm{~mm}$ were observed in the central sector, near the salt mine (time series 2 ), and smaller ones were observed at the hill borders (time series 1 and 2; Figure 11c). Our observations are in agreement with Guerricchio, A. et al. [54] (Figure 11b).
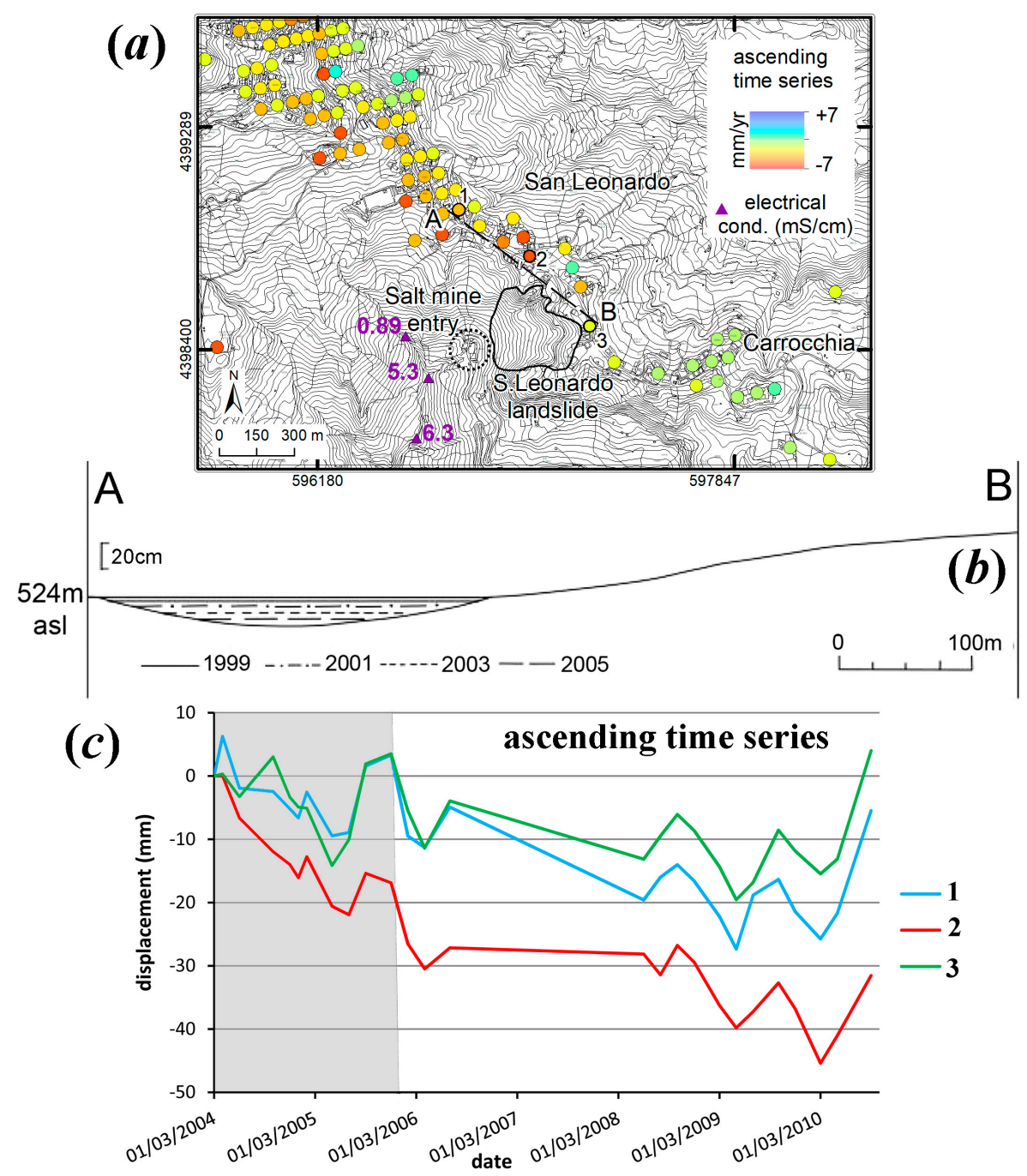

Figure 11. (a) Ascending ground velocity map for Lungro village. Violet triangles represent the measurements of electrical conductivity $(\mathrm{mS} / \mathrm{cm})$ along the streams, testifying the still active halite dissolution. See the inset in Figure 3a for the area location; (b) monitoring of subsidence phenomena in the San Leonardo locality by means of topographic survey (from Guerricchio, A. et al. [54]); (c) Envisat ascending time series for the investigated area; their location is shown by black circles in Figure 11a. The gray background represents the temporal interval covered also by topographic data.

\section{Discussion}

We now try to explain the deformation patterns in the CV by comparing our InSAR observations with available geological, tectonic, and geomorphological information.

\subsection{Subsidence, CV Plain}

Subsidence affects the CV alluvial plain where important infrastructures are present, such as the A3 highway (Salerno-Reggio Calabria, Figure 4a). Although the CV graben is bounded by active N-S striking normal faults that cause widespread seismicity (Figure 2), we are not able to detect a tectonic 
signal associated with subsidence. This is probably due to the resolution and short time span of our satellite observations compared to the time scale of the subsidence and tectonic processes in the region.

Then, we need to focus our attention on other detectable causes of ground motion. Water depletion in compressible soils could increase the long-term subsidence processes, as observed in other Quaternary basins [56,57]. We do find a correspondence between areas characterized by groundwater drawdowns and the main subsidence rates detected by InSAR (Figure 7). Compaction of the sedimentary infill in the alluvial plain, which thickens towards the Sila foothills (Spina, V. et al. [24]), is a predominant factor affecting ground movement. Groundwater exploitation in this area is testified by the presence of numerous active wells (Figure 2).

Another factor behind sediment consolidation and subsidence in the $\mathrm{CV}$ is urban expansion (e.g., the Quattromiglia area, Figure 6). This link has also been observed in other quaternary basins (see for example Polcari, M. et al. [58]).

At Cosenza, the transition between weak uplift in the eastern sector and weak subsidence in the west could be explained by the lateral passage from the Pliocene deposits and Quaternary conglomerates to the more compressible alluvial Quaternary sediments. More detailed information, such as hydrogeological data, is necessary to better explain the weak uplift observed in eastern Cosenza sector, but it is not currently available.

Finally, we detected another cause of ground motion. From our detailed analysis, we detected ground instability close to San Leonardo hill in the Lungro village area, which is most likely related to salt mining. The high water electrical conductivity (around $6 \mathrm{mS} / \mathrm{cm}$ ) recorded downstream from the salt mine in the Burrone della Salina stream $(5.7 \mathrm{mS} / \mathrm{cm})$ and the Fiumicello River $(6.3 \mathrm{mS} / \mathrm{cm}$; Figure 11a) are indicative of the active halite dissolution in the mine. From the ascending data, we deduced the greatest displacement in the middle sector of the San Leonardo hill, which we explain as due to subsidence after taking into account the topographic survey of Guerricchio, A. et al. [54]. The observed deformation and the still active halite dissolution suggest the key role of subsidence as a triggering and controlling factor for landslides. This type of subsidence has been observed in other old mines, such as for example the Wieliczka salt mine (Poland) [59] and the Pasquasia potassic salt mine (Italy) [60].

\subsection{Landslides, CV Slopes}

The visibility of landslide-affected areas depends on the SAR acquisition geometry. The eastern slope is more visible on the ascending Envisat track, while the western slope is more visible on the descending track (Figure 12). Along the slopes, ground movement is observed for an area extending $\sim 86 \mathrm{~km}^{2}$ : Of this activity, $46.2 \%$ is visible in the ascending track, and $17.7 \%$ is visible in the descending track. Only a small part of the landslides mapped by the PAI inventory is covered by coherent pixels (recording the slope movement). In particular, ascending coherent pixels cover 19.7\% of the PAI landslides, while descending coherent pixels cover $6.5 \%$ of the landslides in PAI. In this calculation, the landslide area should include at least one coherent pixel.

We take $1.5 \mathrm{~mm}$ /year as the displacement rate threshold to discriminate movement from absence of movement, in agreement with Cascini, L. et al. [10]. Under this assumption, some of our observations point to slope movement in areas that the PAI identifies as dormant landslides, or an absence of movement in areas where landslides are classified as active (Figure 13). This disagreement could be due to the evolution of the landslides over time (i.e., reactivation and stabilization) following the state of activity that was defined in the PAI (compiled in 2001, last update in 2011). 

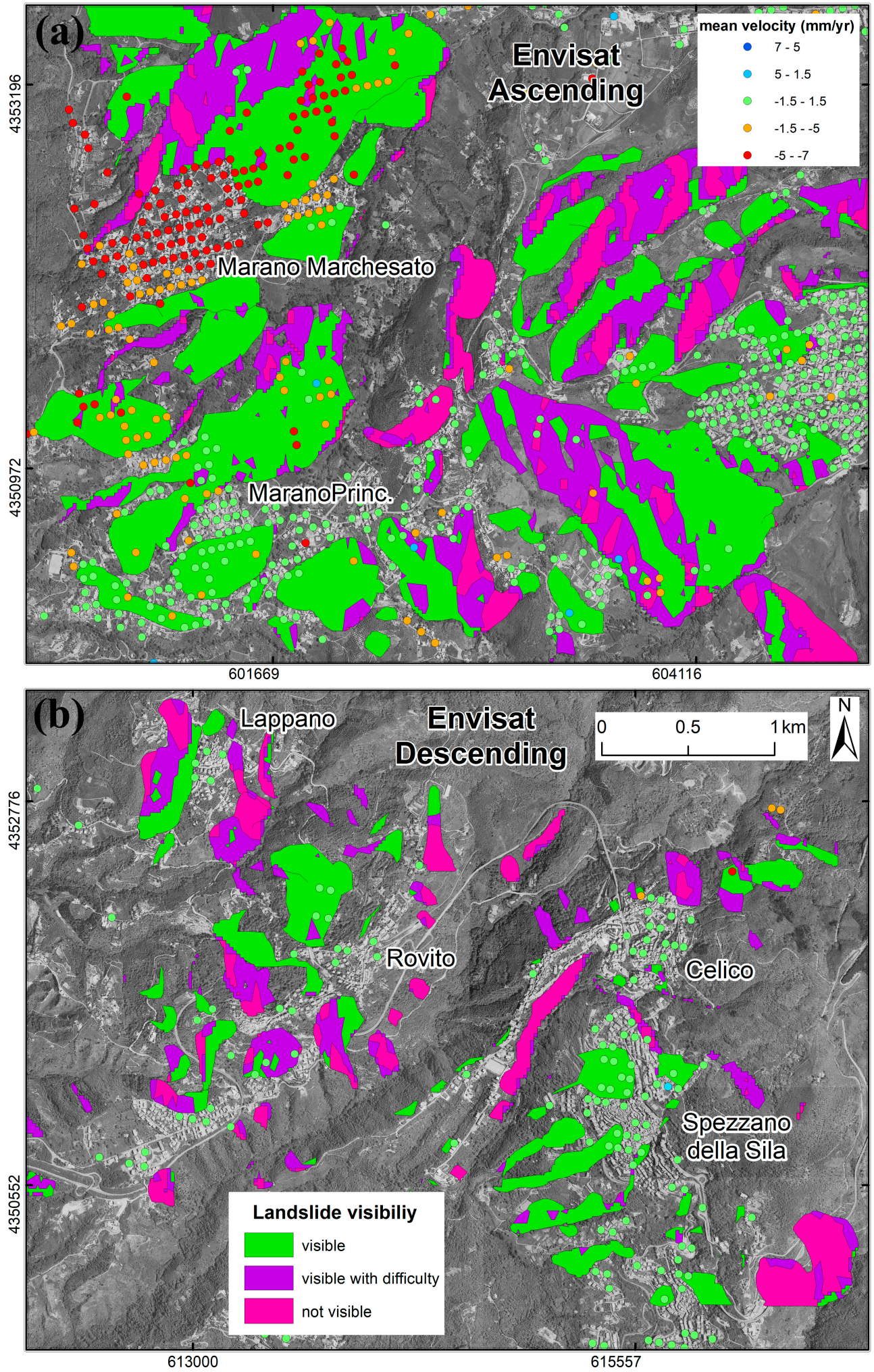

Figure 12. Illustrative extracts of the "a priori landslide visibility map" on (a) ascending and (b) descending orbits with the low-resolution coherent pixels (represented by colored circles). Such maps are verified if the landslide area is visible for the ascending (a) or descending (b) SAR mean ground velocity. In the areas located along the western side of the $\mathrm{CV}$, mainly facing east, the landslides are more visible on the ascending orbit (a); on the contrary, along the eastern side, mainly facing west, the landslides are more visible on the descending orbit (b). See Figure $5 b$ (inset 2 and 3 ) for the location of two sample areas. 

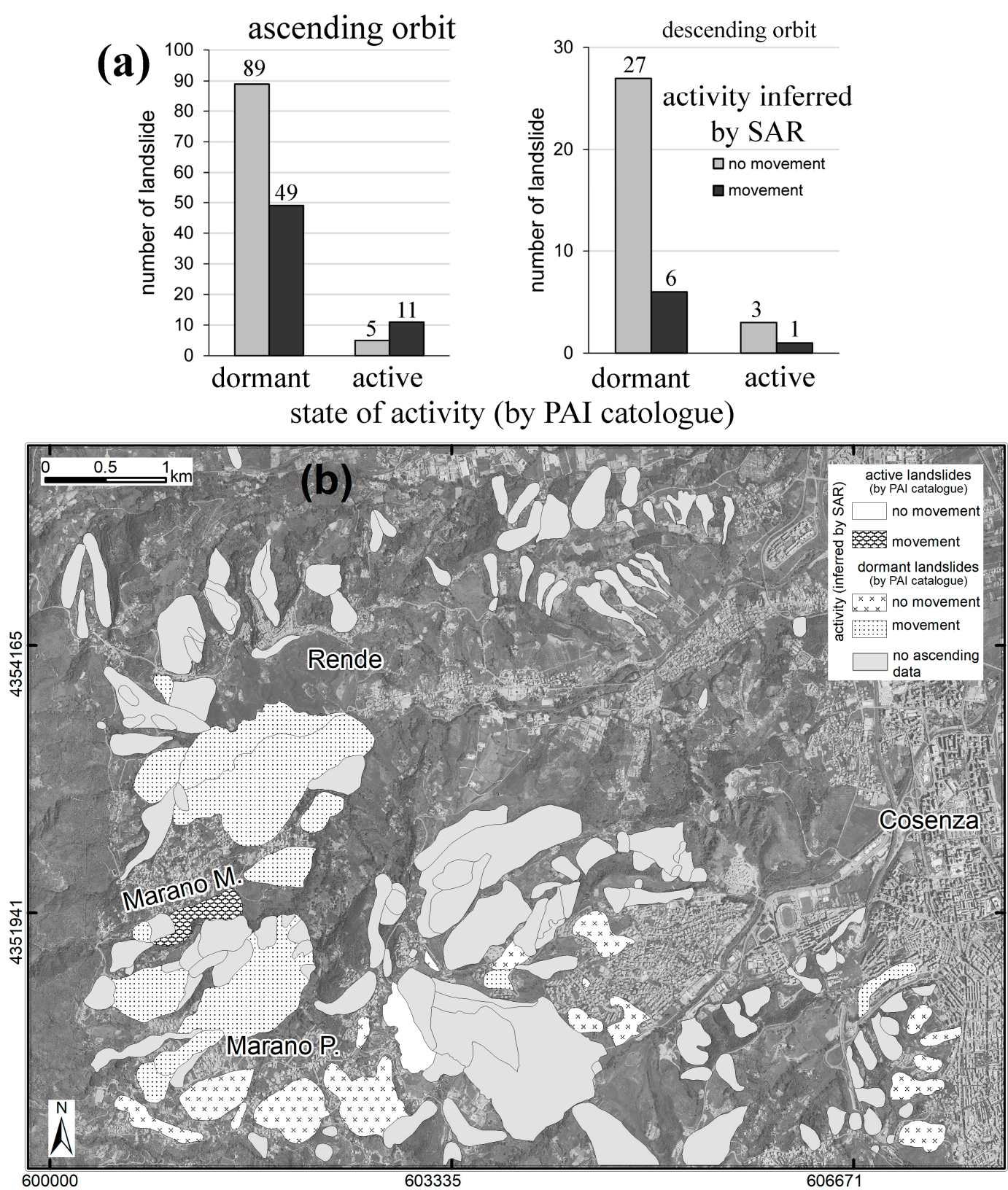

Figure 13. (a) Comparison between the state of activity based on geomorphological evidences (PAI inventory map) and the evidence of movement shown by Envisat ascending and descending datasets; (b) evidence of movement or no movement according to ascending data for a portion of the investigated area. We compared the state of activity inferred by the PAI catalogue and the velocities of the SAR pixels included in the landslides bodies (e.g., Figure 12a).

To further explore this finding, we selected and analyzed the time series of four cases in the group of landslides that are classified as dormant in PAI, but show evidence of movement from SAR. We examined the ascending time series (Figure 14b) of MM1, MM12 (both are deep landslide areas located close to Marano Marchesato village), and RG7 (a complex landslide area close to Rota Greca municipality), and the descending time series (Figure 14c) of ROS13 (a rotational slide near Rose village). All of the ascending time series (Figure 14b) show a continuous increase of displacement, with the greatest rates occurring between 2006 and 2008, and at the beginning of 2009. 
(a)

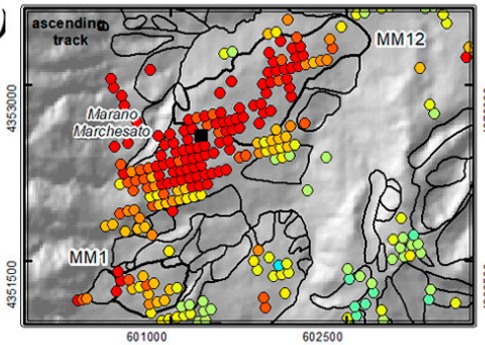

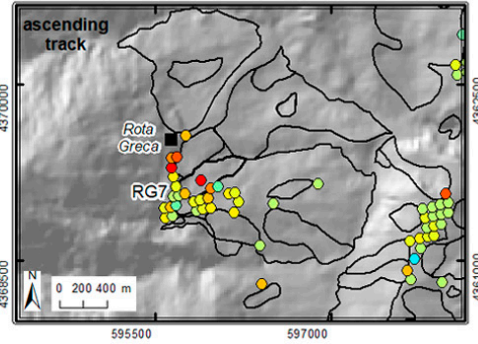

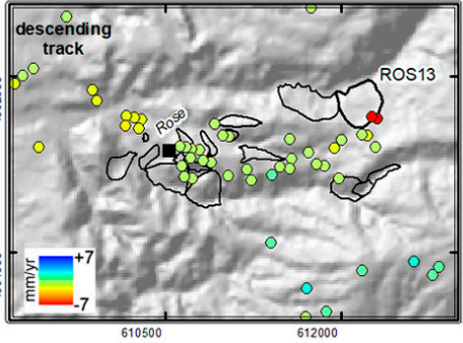

descending time
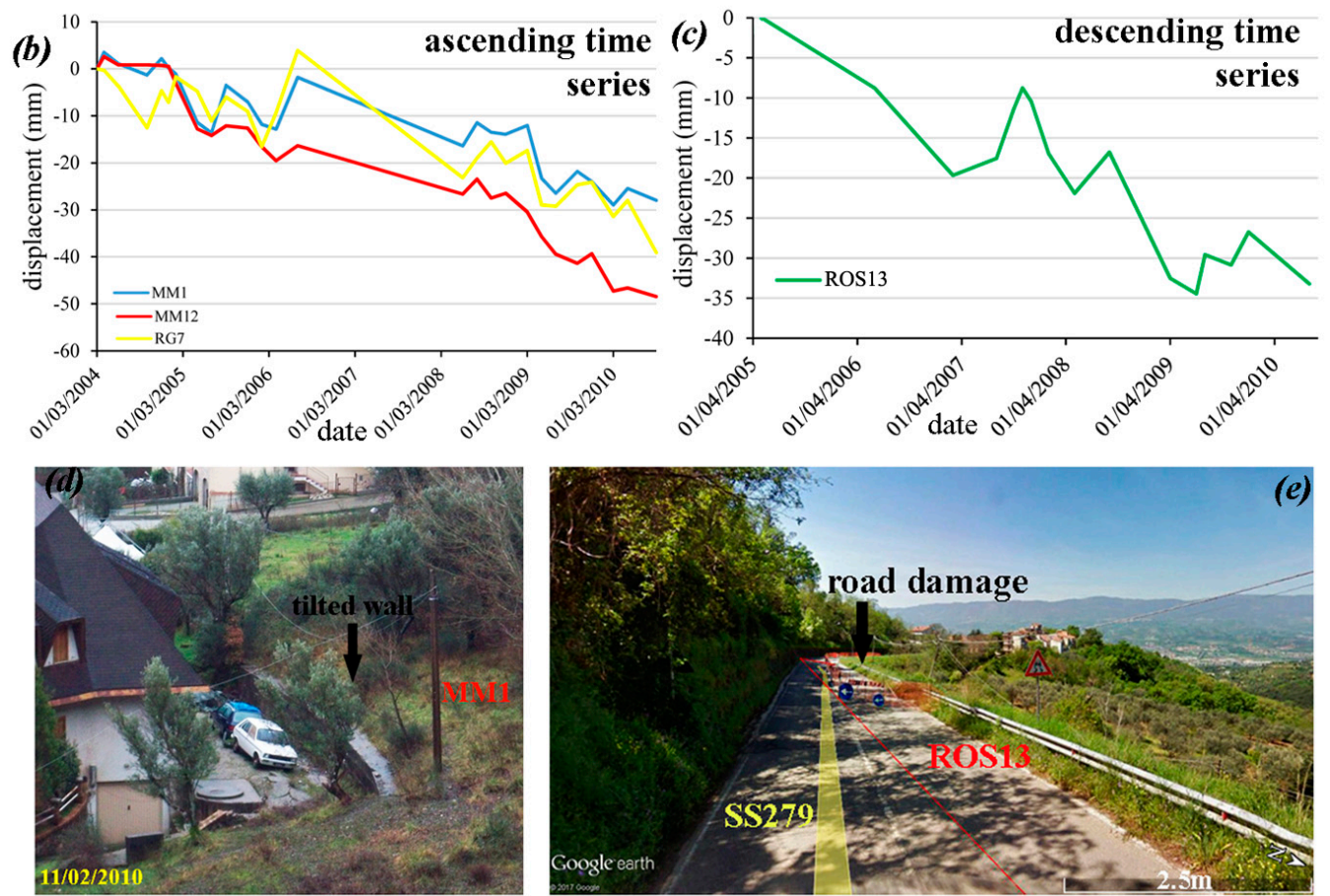

Figure 14. (a) Location of the analyzed time series; (b) ascending time series of the MM1, MM12 (both close to Marano Marchesato village), and RG7 (near Rota Greca) landslides; (c) descending time series of the ROS13 landslide located close to Rose village; (d) tilted wall placed inside the MM1 landslide (photo courtesy of Geol. P. Basta); (e) damage of the road SP279 due to the ROS13 landslide (image from Google Earth street view).

The increase in 2009 can be correlated to the rainfall peak recorded by the Cosenza and Montalto rain gauges (Arpacal—http:/ / www.cfd.calabria.it/index.php/dati-stazioni). Also, the descending time series of the ROS13 landslide (Figure 14b) shows increasing displacement, with the maximum rate occurring between the end of 2008 and the beginning of 2009. This maximum value is associated to a rainfall peak occurring during the same period (recorded near San Pietro in the Guarano rain gauge of ArpaCal). The activity of these landslides (MM1 and ROS13) is testified by the deformation of ground and man-made structures (Figure 14d,e). Furthermore, the increase of landslide displacement, recorded during the winter of 2008-2009, is likely due to hydrogeological instability caused by intense rainfall in the Calabria region during the same period [61].

Finally, the mean displacement rates inferred by SAR suggest that some landslides mapped by PAI as dormant might in fact be active, similarly to the Rende and San Fili areas, as proposed by Bianchini, S. et al. [62].

\section{Conclusions}

The Crati Valley (CV) in the Calabria Region (Southern Italy) is located in one of the most risk-prone areas of the Italian peninsula in terms of seismic and hydrogeological hazard. Observation 
of ground deformation from space has become a fundamental tool in hazard evaluation. Our analysis of remote sensed SAR data shows that the spatial and temporal evolution of ground deformation in the $\mathrm{CV}$ mainly occurs as subsidence in the alluvial plane and landslides on the slopes. We consider InSAR data processed from more than 70 images collected along both ascending and descending Envisat tracks during April 2003-September 2010. A main objective of this work was to determine the possible causes behind ground motion by comparing SAR data with other independent observations.

Subsidence is the result of several mechanisms. In our case, the compaction of the recent alluvial deposits seems to be the main cause. There is an anthropogenic contribution to the observed subsidence, namely compaction by groundwater exploitation and fast urban sprawl. We are not able to detect the tectonic contribution to the signal associated with subsidence, although we cannot exclude the presence of vertical movements due to the activity of normal faults bounding the valley.

A comparison of our observations with the PAI landslide catalog shows discrepancies between the activity classified in the catalog, and the displacement measured by InSAR. In particular, some landslide activity might be underestimated in the PAI. We believe that satellite-based techniques represent a useful tool to update large landslides catalogs, as also suggested by other authors (e.g., Cascini, L. et al. [63].

Our detailed analysis of the S. Leonardo locality (Lungro village) shows that a landslide near the old salt mine caused westward and high subsidence velocities. This particular case is interesting, since it shows the interaction between subsidence and landslide activity. Here, halite dissolution and the collapse due to mine excavations represent both a triggering and control mechanism for the $\mathrm{S}$. Leonardo landslide.

The next steps to increase our knowledge of ground deformation space-time evolution in this area are: (1) to extend the satellite SAR displacement time series; and (2) to add data from other missions, especially from the higher resolution and/or recent acquisition systems (e.g., COSMO-SkyMed and Sentinel-1 constellations).

This effort might allow for further discrimination of the different causes of ground displacement, in particular the tectonic contribution.

Acknowledgments: Giuseppe Cianflone and Rocco Dominici are supported by the project "Sperimentazione di metodologie per la valutazione della pericolosità idraulica, da frana e da erosione costiera e loro applicazioni per la validazione della perimetrazione del Piano di Assetto Idrogeologico approvate dall'Autorità di Bacino per il conseguimento del fine comune della Ricerca scientifica e loro applicazioni nell'ambito dei rispettivi fini istituzionali" funded by Autorità di Bacino of Regione Calabria. The Envisat images are provided by ESA (European Space Agency) under the CAT.1P 5605. We thank Paolo Riccardi and Alessio Cantone (Sarmap, CH) for the fruitful collaboration and useful suggestions during the SAR data processing. We also thank Enrico Serpelloni (INGV-Bo) for providing the GPS solutions. We thank the three anonymous reviewer for their comments, which helped to improve the manuscript.

Author Contributions: All authors participated in the writing of the manuscript. Giuseppe Cianflone developed the project and conducted the geological survey. Cristiano Tolomei processed the SAR data. All authors analyzed and interpreted the data.

Conflicts of Interest: The authors declare no conflict of interest.

\section{References}

1. Gabriel, A.K.; Goldstein, R.M.; Zebker, H.A. Mapping small elevation changes over large areas: Differential radar interferometry. J. Geophys. Res. 1989, 94, 9183-9191. [CrossRef]

2. Ferretti, A.; Prati, C.; Rocca, F. Permanent Scatters in SAR interferometry. IEEE Trans. Geosci. Remote Sens. 2001, 39, 8-20. [CrossRef]

3. Berardino, P.; Fornaro, G.; Lanari, R.; Sansosti, E. A new algorithm for surface deformation monitoring based on small baseline differential SAR interferograms. IEEE Trans. Geosci. Remote Sens. 2002, 40, 2375-2383. [CrossRef]

4. Hooper, A. A multi-temporal InSAR method incorporating both persistent scatterer and small baseline approaches. Geophys. Res. Lett. 2008, 35, L16302. [CrossRef] 
5. Ferretti, A.; Fumagalli, A.; Novalli, F.; Prati, C.; Rocca, F.; Rucci, A. A new algorithm for processing interferometric data-stacks: SqueeSAR. IEEE Trans. Geosci. Remote Sens. 2001, 49, 3460-3470. [CrossRef]

6. Brunori, C.A.; Bignami, C.; Albano, M.; Zucca, F.; Samsonov, S.; Groppelli, G. Land subsidence, ground fissures and buried faults: InSAR monitoring of Ciudad Guzmán (Jalisco-Mexico). Remote Sens. 2015, 7, 8610-8630. [CrossRef]

7. Guzzetti, F.; Manunta, M.; Ardizzone, F.; Pepe, A.; Cardinali, M.; Zeni, G.; Reichenbach, P.; Lanari, R. Analysis of ground deformations detected using the SBAS-DInSAR technique in Umbria, Central Italy. Pure Appl. Geophys. 2009, 166, 1425-1459. [CrossRef]

8. Polcari, M.; Albano, M.; Saroli, M.; Tolomei, C.; Lancia, M.; Moro, M.; Stramondo, S. Subsidence detected by multi-pass differential SAR interferometry in the Cassino plain (Central Italy): Joint effect of geological and anthropogenic factors? Remote Sens. 2014, 6, 9676-9690. [CrossRef]

9. Stramondo, S.; Saroli, M.; Tolomei, C.; Moro, M.; Doumaz, F.; Pesci, A.; Loddo, F.; Baldi, P.; Boschi, E. Surface movements in Bologna (Po Plain-Italy) detected by multitemporal DInSAR. Remote Sens. Environ. 2007, 110, 304-316. [CrossRef]

10. Cascini, L.; Fornaro, G.; Peduto, D. Analysis at medium scale of low-resolution DInSAR data in slow-moving landslide-affected areas. ISPRS J. Photogramm. Remote Sens. 2009, 64, 598-611. [CrossRef]

11. Cascini, L.; Fornaro, G.; Peduto, D. Advanced low- and full-resolution DInSAR map generation for slow-moving landslide analysis at different scales. Eng. Geol. 2010, 112, 29-42. [CrossRef]

12. Notti, D.; Calò, F.; Cigna, F.; Manunta, M.; Herrera, G.; Berti, M.; Meisina, C.; Tapete, D.; Zucca, F. A useroriented methodology for DInSAR time series analysis and interpretation: Landslides and subsidence case studies. Pure Appl. Geophys. 2015, 172, 3081-3105. [CrossRef]

13. Zebker, H.A.; Rosen, P.A.; Goldstein, R.M.; Gabriel, A.; Werner, C.L. On the derivation of coseismic displacement fields using differential radar interferometry: The landers earthquake. J. Geophys. Res. 1994, 99, 19617-19634. [CrossRef]

14. Moro, M.; Saroli, M.; Tolomei, C.; Salvi, S. Insights on the kinematics of deep-seated gravitational slope deformations along the 1915 Avezzano earthquake fault (Central Italy), from time-series DInSAR. Geomorphology 2009, 112, 261-276. [CrossRef]

15. Moro, M.; Cannelli, V.; Chini, M.; Bignami, C.; Melini, D.; Stramondo, S.; Saroli, M.; Picchiani, M.; Kyriakopoulos, C.; Brunori, C.A. The October 23, 2011, Van (Turkey) earthquake and its relationship with neighbouring structures. Sci. Rep. 2014, 4, 1-8. [CrossRef] [PubMed]

16. Jiang, H.; Feng, G.; Wang, T.; Bürgmann, R. Toward full exploitation of coherent and incoherent information in Sentinel-1 TOPS data for retrieving surface displacement: Application to the 2016 Kumamoto (Japan) earthquake. Geophys. Res. Lett. 2017, 44, 1758-1767. [CrossRef]

17. Brunori, C.A.; Bignami, C.; Stramondo, S.; Bustos, E. 20 years of active deformation on volcano caldera: Joint analysis of InSAR and AInSAR techniques. Int. J. Appl. Earth Obs. Geoinf. 2013, 23, 279-287. [CrossRef]

18. Spina, V.; Tondi, E.; Galli, P.; Mazzoli, S. Fault propagation in a seismic gap area (northern Calabria, Italy): Implication for seismic hazard. Tectonophysics 2009, 476, 357-369. [CrossRef]

19. Monaco, C.; Tortorici, L. Active faulting in the Calabrian Arc and eastern Sicily. J. Geodyn. 2000, $29,407-424$. [CrossRef]

20. Scandone, P. Origin of the Thyrrenian Sea and Calabrian Arc. Boll. Soc. Geol. Ital. 1979, 98, 27-34.

21. Tortorici, L.; Monaco, C.; Tansi, C.; Cocina, O. Recent and active tectonics in the Calabrian arc (Southern Italy). Tectonophysics 1995, 234, 37-55. [CrossRef]

22. Mattei, M.; Cipollari, P.; Cosentino, D.; Argentieri, A.; Rossetti, F.; Speranza, F.; Di Bella, L. The Miocene tectono-sedimentary evolution of the Southern Tyrrhenian Sea: Stratigraphy, structural and paleomagnetic data from the onshore Amantea basin (Calabrian Arc, Italy). Basin Res. 2002, 14, 147-168. [CrossRef]

23. Tansi, C.; Muto, F.; Critelli, S.; Iovine, G. Neogene-Quaternary strike-slipe tectonics in the central Calabrian Arc (southern Italy). J. Geodyn. 2007, 43, 393-414. [CrossRef]

24. Spina, V.; Tondi, E.; Mazzoli, S. Complex basin development in a wrench-dominated back-arc area: Tectonic evolution of the Crati Basin, Calabria, Italy. J. Geodyn. 2011, 51, 90-109. [CrossRef]

25. Galli, P.; Bosi, V. Catastrophic 1638 earthquakes in Calabria (southern Italy): New insights from palaeoseismological investigation. J. Geophys. Res. 2004, 108. [CrossRef]

26. Pondrelli, S.; Salimbeni, S.; Ekström, G.; Morelli, A.; Gasperini, P.; Vannucci, G. The Italian CMT dataset from 1977 to the present. Phys. Earth Planet. Inter. 2006, 159, 286-303. [CrossRef] 
27. Scognamiglio, L.; Tinti, E.; Michelini, A. Real-time determination of seismic moment tensor for the Italian region. Bull. Seismol. Soc. Am. 2009, 99, 2223-2242. [CrossRef]

28. Mattei, M.; Cifelli, F.; D'Agostino, N. The evolution of the Calabrian Arc: Evidence from paleomagnetic and GPS observations. Earth Planet. Sci. Lett. 2007, 263, 259-274. [CrossRef]

29. Casula, G. Geodynamics of the Calabrian Arc area (Italy) inferred from a dense GNSS network observations. Geodes. Geodyn. 2016, 7, 76-86. [CrossRef]

30. Lanzafame, G.; Zuffa, G.G. Geologia e petrografia del Foglio di Bisignano (Bacino del Crati, Calabria): Carta geologica alla scala 1:50000. Geol. Rom. 1976, 15, 223-270.

31. Di Nocera, S.; Ortolani, F.; Russo, B.; Torre, M. Successioni sedimentarie Messiniane al limite Miocene-Pliocene nella Calabria settentrionale. Boll. Soc. Geol. Ital. 1987, 93, 575-607.

32. Colella, A.; de Boer, P.L.; Nio, S.D. Sedimentology of a marine intermontane Pleistocene Gilbert-type fan-delta complex in the Crati Basin, Calabria, southern Italy. Sedimentology 1987, 34, 721-736. [CrossRef]

33. Fabbricatore, D.; Robustelli, G.; Muto, F. Facies analysis and depositional architecture of shelf-type deltas in the Crati Basin (Calabrian Arc, South Italy). Ital. J. Geosci. 2014, 133, 131-148. [CrossRef]

34. Sorriso-Valvo, M.; Tansi, C. Grandi frane e deformazioni gravitative profonde di versante della Calabria. Note illustrative per la carta al 250.000. Geogr. Fis. Din. Quat. 1996, 19, 395-408.

35. Tansi, C.; Tallarico, A.; Iovine, G.; Folino Gallo, M.; Falcone, G. Interpretation of radon anomalies in seismotectonic and tectonic-gravitational settings: The south-eastern Crati graben (Northern Calabria, Italy). Tectonophysics 2005, 396, 181-193. [CrossRef]

36. Tansi, C.; Iovine, G.; Folino Gallo, M. Tettonica attiva e recente, manifestazioni gravitative profonde, lungo il bordo orientale del graben del Fiume Crati (Calabria settentrionale). Boll. Soc. Geol. Ital. 2005, 124, 563-578.

37. Raspini, F.; Cigna, F.; Moretti, S. Multi-temporal mapping of land subsidence at basin scale exploiting Persistent Scatterer Interferometry: Case study of Gioia Tauro plain (Italy). J. Maps 2012, 8, 514-524. [CrossRef]

38. Cianflone, G.; Tolomei, C.; Brunori, C.A.; Dominici, R. InSAR time series analysis of natural and anthropogenic coastal plain subsidence: The case of Sibari (Southern Italy). Remote Sens. 2015, 7, 16004-16023. [CrossRef]

39. Comerci, V.; Blumetti, A.M.; Di Manna, P.; Fiorenza, D.; Guerrieri, L.; Lucarini, M.; Serva, L.; Vittori, E. ITHACA Project and capable faults in the Po Plain (Northern Italy). Ing. Sismica 2013, 30, 36-45.

40. Rovida, A.; Locati, M.; Camassi, R.; Lolli, B.; Gasperini, P. (Eds.) CPTI15, the 2015 version of the Parametric Catalogue of Italian Earthquakes. Ist. Naz. Geofis. Vulcanol. 2016. [CrossRef]

41. Massonnet, D.; Feigl, K.L. Radar interferometry and its application to changes in the earth's surface. Rev. Geophys. 1998, 36, 441-500. [CrossRef]

42. Bvrgmann, R.; Rosen, P.A.; Fielding, E.J. Synthetic aperture radar interferometry to measure Earth's surface topography and its deformation. Annu. Rev. Earth Planet. Sci. 2000, 28, 169-209. [CrossRef]

43. Hanssen, R. Radar Interferometry: Data Interpretation and Error Analysis; Kluwer Academic Publisher: Dordrecht, The Netherlands, 2001.

44. Casu, F.; Manzo, M.; Lanari, R. A quantitative assessment of the SBAS algorithm performance for surface deformation retrieval from DInSAR data. Remote Sens. Environ. 2006, 102, 195-210. [CrossRef]

45. Goldstein, R.M.; Zebker, H.A.; Werner, C.L. Satellite radar interferometry: Two-dimensional phase unwrapping. Radio Sci. 1988, 23, 713-720. [CrossRef]

46. Pepe, A.; Lanari, R. On the extension of the minimum cost flow algorithm for phase unwrapping of multitemporal differential SAR interferograms. Trans. Geosci. Remote Sens. 2006, 44, 2374-2383. [CrossRef]

47. De Luca, C.; Cuccu, R.; Elefante, S.; Zinno, I.; Manunta, M.; Casola, V.; Rivolta, G.; Lanari, R.; Casu, F. An on-demand web tool for the unsupervised retrieval of earth's surface deformation from SAR data: The P-SBAS service within the ESA G-POD environment. Remote Sens. 2015, 7, 15630-15650. [CrossRef]

48. Farr, T.G.; Kobrick, M. Shuttle Radar Topography Mission produces a wealth of data. Eos 2000, 81, 583-585. [CrossRef]

49. Celico, F.; De Vita, P.; Monacelli, G.; Scalise, A.R.; Tranfaglia, G. Carta Idrogeologica dell'Italia Meridionale; Istituto Poligrafico e Zecca dello Stato: Rome, Italy, 1999.

50. Montuori, A.; Luzi, G.; Bignami, C.; Gaudiosi, I.; Stramondo, S.; Crosetto, M.; Buongiorno, F. The interferometric use of radar sensors for the urban monitoring of structural vibrations and surface displacements. IEEE J. Sel. Top. Appl. Earth Obs. Remote Sens. 2016, 9, 3761-3776. [CrossRef] 
51. Almagià, R. Studi Geografici Sulle Frane in Italia: L'Appennino Centrale e Meridionale. Conclusioni Generali; Società Geografica Italiana: Rome, Italy, 1910.

52. Guerricchio, A.; Bruno, F.; Mastromattei, R. Centri abitati instabili in Calabria: Deformazioni gravitative profonde di versante e grandi frane nel territorio comunale di Lungro (Calabria settentrionale). Geol. Appl. Idrogeol. 1993, 28, 479-488.

53. Antronico, L.; Borrelli, L.; Peduto, D.; Fornaro, G.; Gullà, G.; Paglia, L.; Zeni, G. Conventional and innovative techniques for the monitoring of displacements in landslide affected area. In Landslide Science and Practice, 2nd ed.; Margottini, C., Canuti, P., Sassa, K., Eds.; Springer: Berlin, Germany, 2013.

54. Guerricchio, A.; Biamonte, V.; Mastromattei, R.; Ponte, M. Land subsidence induced by slow gravitational deformations and by digging of rock-salt in S. Leonardo territory (Lungro town, Calabria region, Southern Italy). In Proceedings of the 7th Symposium on Land Subsidence, Shanghai, China, 23-28 October 2005.

55. Cortese, D.; Domestico, G. Lungro Città del Sale; TNT gr@fica: Spezzano Albanese (Cs), Italy, 2010.

56. Bonì, R.; Herrera, G.; Meisina, C.; Notti, D.; Béjar-Pizarro, M.; Zucca, F.; Gonzàlez, P.J.; Palano, M.; Tomàs, R.; Fernàndez, J.; et al. Twenty-year advanced DIn-SAR analysis of severe land subsidence: The Alto Guadalent’in Basin (Spain) case study. Eng. Geol. 2015, 198, 40-52. [CrossRef]

57. Bozzano, F.; Esposito, C.; Franchi, S.; Mazzanti, P.; Perissin, D.; Rocca, A.; Romano, E. Understanding the subsidence process of a quaternary plain by combining geological and hydrogeological modelling with satellite InSAR data: The Acque Albule Plain case study. Remote Sens. Environ. 2015, 168, 219-238. [CrossRef]

58. Xu, B.; Feng, G.; Li, Z.; Wang, Q.; Wang, C.; Xie, R. Coastal subsidence monitoring associated with land reclamation using the point target based SBAS-InSAR method: A case study of Shenzhen, China. Remote Sens. 2016, 8, 652. [CrossRef]

59. Perski, Z.; Hanssen, R.; Wojcik, A.; Wojciechowski, T. InSAR analyses of terrain deformation near the Wieliczka Salt Mine, Poland. Eng. Geol. 2009, 106, 58-67. [CrossRef]

60. Vallone, P.; Giammarinaro, M.S.; Costa, D.; Crosetto, M. Subsidence hazard in potassic salts mines. In Proceedings of the 3rd International Conference on Applied Geophysics for Engineering, Messina, Italy, 11-15 October 2006.

61. Cetemps. Available online: http://cetemps.aquila.infn.it/chym/valid/index_files/CNR_Calabria_Report. pdf (accessed on 17 January 2017).

62. Bianchini, S.; Cigna, F.; Righini, G.; Proietti, C.; Casagli, N. Landslide HotSpot Mapping by means of Persistent Scatterer Interferometry. Environ. Earth Sci. 2012, 67, 1155-1172. [CrossRef]

63. Bouali, E.H.; Oommen, T.; Escobar-Wolf, R. Mapping of slow landslides on the Palos Verdes Peninsula using the California landslide inventory and persistent scatterer interferometry. Landslides 2017, 1-14. [CrossRef] 